\title{
Current Progress of Jatropha Curcas Commoditisation as Biodiesel Feedstock: A Comprehensive Review
}

OPEN ACCESS

Edited by:

Zhongyang Luo,

Zhejiang University, China

Reviewed by:

István Barabás,

Technical University of Cluj-Napoca,

Romania

Kumaran Kadirgama,

Universiti Malaysia Pahang, Malaysia

*Correspondence:

T. M. I. Riayatsyah

t.indra@ms.itera.ac.id

T. M. I. Mahlia

TMIndra.Mahlia@uts.edu.au/indra@

uniten.edu.my

Specialty section: This article was submitted to

Bioenergy and Biofuels,

a section of the journal

Frontiers in Energy Research

Received: 15 November 2021

Accepted: 27 December 2021

Published: 14 January 2022

Citation:

Riayatsyah TMI, Sebayang AH, Silitonga AS, Padli Y, Fattah IMR, Kusumo F, Ong HC and Mahlia TMI (2022) Current Progress of Jatropha Curcas Commoditisation as Biodiesel Feedstock: A Comprehensive Review.

Front. Energy Res. 9:815416.

doi: 10.3389/fenrg.2021.815416

\author{
T. M. I. Riayatsyah ${ }^{1 *}$, A. H. Sebayang ${ }^{2}$, A. S. Silitonga ${ }^{2}$, Y. Padli $^{3}$, I. M. R. Fattah ${ }^{4}$, F. Kusumo ${ }^{4}$ \\ H. C. Ong ${ }^{5}$ and T. M. I. Mahlia ${ }^{4 *}$
}

${ }^{1}$ Mechanical Engineering Program, Institut Teknologi Sumatera (ITERA), Lampung, Indonesia, ${ }^{2}$ Department of Mechanical Engineering, Politeknik Negeri Medan, Medan, Indonesia, ${ }^{3}$ School of Chemical and Biomolecular Engineering, the University of Sydney, Sydney, NSW, Australia, ${ }^{4}$ Centre for Green Technology (CGT), Faculty of Engineering and Information Technology, University of Technology Sydney, Sydney, NSW, Australia, ${ }^{5}$ Future Technology Research Center, National Yunlin University of Science and Technology, Douliou, Taiwan

This article looks at the national and global actors, social networks, and narratives that have influenced Jatropha's worldwide acceptability as a biofuel crop. Jatropha Curcas is a genus of around 175 succulent shrubs and trees in the Euphorbiaceae family (some of which are deciduous, such as Jatropha Curcas L.). It's a drought-tolerant perennial that thrives in poor or marginal soil and produces a large amount of oil per hectare. It is easy to grow, has a fast growth rate, and can generate seeds for up to 50 years. Jatropha Curcas has been developed as a unique and promising tropical plant for augmenting renewable energy sources due to its various benefits. It is deserving of being recognised as the only competitor in terms of concrete and intangible environmental advantages. Jatropha Curcas is a low-cost biodiesel feedstock with good fuel properties and more oil than other species. It is a non-edible oilseed feedstock. Thus it will have no impact on food prices or the food vs fuel debate. Jatropha Curcas emits fewer pollutants than diesel and may be used in diesel engines with equivalent performance. Jatropha Curcas also makes a substantial contribution to the betterment of rural life. The plant may also provide up to $40 \%$ oil yield per seed based on weight. This study looks at the features characteristics of Jatropha Curcas as biodiesel feedstock and performance, and emissions of internal combustion engine that operates on this biodiesel fuel.

Keywords: Jatropha biodiesel, biodiesel properties, engine performance, engine emission, economic viability

\section{INTRODUCTION}

One of the most major sources of pollution in the environment is pollutants created by the burning of fossil diesel fuel. Diesel engine pollutants have a substantial impact on both the environment and human health. Researchers are looking into the clean combustion of diesel engines using other fuel sources due to a number of factors, including worldwide environmental concerns, growing petroleum costs, and the expected depletion of fossil diesel fuel. For decades, scientists have been working throughout the world to discover new alternative fuels that are widely available, technically feasible, economically viable, and environmentally beneficial (Valipour, 2014).

Alternative energy sources are needed to address the world's growing energy demands. Biodiesel fuels are being researched as a possible replacement for diesel due to the predicted future depletion of fossil fuel sources and the present rising cost of such fuels. It has a higher cetane index and emits less carbon dioxide emissions, among other advantages. Biodiesel is a 
clean-burning, oxygenated mono-alkyl ester fuel manufactured from natural, renewable sources like new or used vegetable oils and animal fats (Enweremadu and Mbarawa, 2009). Italy and the United States both saw significant increases in output (where production more than tripled). Thanks to new laws, biodiesel has grown its acceptance and market share in Europe (Lieberz, 2021). In Asia, Singapore, Indonesia, Malaysia and China, as well as Latin America such as in Argentina and Brazil, biodiesel production was quickly rising. Indonesia expects to grow biodiesel production by $23 \%$ by 2030 , while biodiesel usage is expected to rise by $7 \%$ over the next decade. (Kondalamahanty, 2021). In Asia as well as Latin America, biodiesel output was quickly increasing (Argentina and Brazil) (Agarwal, 2007).

Energy supply and security have been a critical concern throughout the globe in the last decade. The combustion of liquid fuels produces energy, which enables a country's economic development and prosperity. Greenhouse gases and other forms of air pollutants are emitted by fossil fuels, which negatively influence the environment. It was also noted that biodiesel is becoming more widely accessible for the transportation sector by mixing with traditional diesel fuel (Sarin et al., 2007). Growing environmental concerns, dwindling petroleum reserves, and our country's agriculturebased economy are all driving reasons behind the promotion of biodiesel to be sustainable transportation fuel.

Biodiesel is a sustainable liquid bioenergy resource that might be used to replace diesel fuel. It has the potential to reduce pollutant emissions and may be used without modification in compression ignition engines. As an alternative fuel, biodiesel possesses qualities that are comparable to diesel fuel. Transesterification is the process of turning large, branching triglycerides into smaller, straight-chain methyl esters in the presence of a solvent, employing an alkali, acid, or enzyme as a catalyst (Fattah et al., 2020). The transesterification process aids in the reduction of oil viscosity. In the presence of homogeneous catalysts such as sodium hydroxide $(\mathrm{NaOH})$, potassium hydroxide (KOH), and sulphuric acid, the method works effectively (Demirbaş, 2002; Salaheldeen et al., 2021). Methanol and ethanol are the most often used solvents, with methanol being favoured due to their inexpensive cost and physical and chemical properties. They efficiently break down sodium hydroxide in these alcohols and react swiftly with triglycerides. Transesterification requires a 3:1 stoichiometric molar ratio of alcohol to triglycerides. To push the equilibrium to a maximum ester yield, the ratio must be greater in reality (Ramesh et al., 2006; Singh and Padhi, 2009; Manik and Prabu, 2013).

Because it contains no sulphur, aromatic hydrocarbons, metals, or crude oil leftovers, biodiesel is an alternative and clean fuel that emits less greenhouse gas emissions. It has the following key benefits: 1) it may be combined with diesel fuel in any quantity, 2) it can be used in a diesel engine without modification, 3) it contains no toxic ingredients, and 4) it emits less harmful pollutants into the environment (How et al., 2012; Ng et al., 2012). Biodiesel is increasing in popularity across the globe, particularly in underdeveloped nations. The first generation of biodiesel feedstocks is edible oils. Edible oils have been used to make biodiesel in the United States and Europe because they are readily accessible, have a high biodiesel production rate, and are simple to process owing to their low free fatty acid content. However, as seen in many countries, particularly in densely populated countries such as China, India, and Indonesia, their use has raised concerns such as food vs fuel concerns, environmental concerns such as the destruction of vital soil resources, deforestation, and the use of much of the available arable land (Mahapatra and Mitchell, 1999; Nurfatriani et al., 2019; Taheripour et al., 2019). All of these problems impeded the economic feasibility of producing biodiesel from food oils. The cost of feedstock is often assumed to contribute to $75 \%$ of the entire cost of biodiesel (soyabean oil, for instance) (Mizik and Gyarmati, 2021). Exploration of innovative low-cost agricultural non-edible crops and the use of by-products in biodiesel production might significantly reduce biodiesel costs, especially in developing countries where edible oils are prohibitively costly (Wang and Ding, 2012; Silitonga et al., 2019; Ambat et al., 2020; Ong et al., 2021).

The first generation biofuel is unsustainable since it competes with edible vegetable oils for food and biodiesel production (Bhatia et al., 2021). Consequently, much effort is being invested into developing biodiesels from non-edible vegetable oils such as Jatropha Curcas. (Takase et al., 2015), Madhuca Indica (Saravanan et al., 2010), Calophyllum Inophyllum (Azad et al., 2016; Milano et al., 2018), Ceiba Pentandra (Putri et al., 2012; Khan et al., 2015), Sapium Sebiferum (Wang et al., 2011), Euphorbia Lathyris (Wang et al., 2011; Zapata et al., 2012), Reutealis Trisperma (Kusmiyati et al., 2019), and Pongamia Pinnata oils (Sharma et al., 2009; Khayoon et al., 2012). Second-generation non-edible feedstocks may assist with food security while also lowering manufacturing costs dramatically. Because non-edible oil has a high percentage of free fatty acids, the biodiesel produced is viscous. Other oil sources must be investigated in order to make biodiesel production more feasible.

The use of Jatropha Curcas as a biodiesel feedstock has exploded in popularity in recent years. It is a tropical plant that may be grown as a commercial crop or as a hedge to protect fields from grazing animals and prevent erosion in low to high rainfall areas (Kumar and Sharma, 2008). This crop's oil can readily be transformed into a liquid biofuel that fulfils American and European requirements for biofuel (Koh and Mohd Ghazi, 2011; Teo et al., 2019). In addition, the press cake may also be used as a fertiliser, and organic waste materials can be digested to produce biogas, the bulk of which is methane (Staubmann et al., 1997; Sharma et al., 2016; Siddiki et al., 2021). The plant itself is said to be capable of preventing and controlling soil erosion, as well as acting as a living barrier and reclaiming wasteland.

A recent review by Che Hamzah et al. (Che Hamzah et al., 2020) highlights the potential of Jatropha Curcas as an environmentally benign biodiesel feedstock for boosting Malaysia's socio-economic growth and meeting the country's rapidly growing energy demands. Singh et al. (Singh D. et al., 


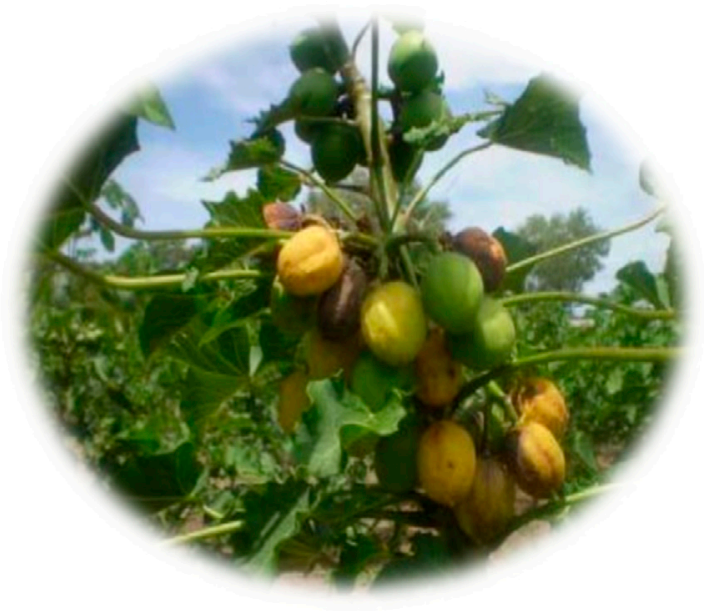

FIGURE 1 | Jatropha Curcas L plants.

2021) reviewed the physicochemical properties, techniques of extracting oil, production of biodiesel, as well as diesel performance and emission characteristics of biodiesel from Jatropha Curcas. However, their study is non-exhaustive, and a comparative analysis of extraction is missing. In another review by Meher et al. (Meher et al., 2013), authors pointed out that tropical and sub-tropical nations have started growing Jatropha curcas to make biodiesel. They suggested methane synthesis from the de-oiled cake, fuel briquette manufacturing from the husk and pyrolysis of Jatropha Curcas biomass to bio-oil with physicochemical qualities equivalent to crude petroleum as additional viable biofuel products from Jatropha Curcas growth. Several authors have also discussed performance and emission characteristics; however, those are outdated. Our present review addresses the botanical description of Jatropha Curcas and oil extraction techniques used by different researchers and oil and biodiesel physicochemical properties to date. Furthermore, the current status of performance and emission research employing Jatropha Curcas biodiesel and its blends is highlighted. Finally economic viability studies along with future research directions are also discussed.

\section{BOTANICAL DESCRIPTION OF JATROPHA CURCAS}

Jatropha Curcas is a drought-resistant shrub or tree that grows wild or in semi-cultivated environments. (Kumar and Sharma, 2008). Depending on soil quality and rainfall, the oil from Jatropha curcas nuts and seeds may be obtained after 2-5 years after cultivation. Jatropha Curcas nuts or seeds are produced in quantities ranging from 0.5 to 12 tonnes per year per hectare. Jatropha Curcas farming is effective in the tropics, where annual rainfall ranges from 250 to 3,000 mm (Foidl et al., 1996). The genus Jatropha Curcas belongs to the Euphorbiaceae family's Jatropheae tribe, and there are roughly 170 species recognised currently (Carels, 2009). The genus Jatropha gets its name from

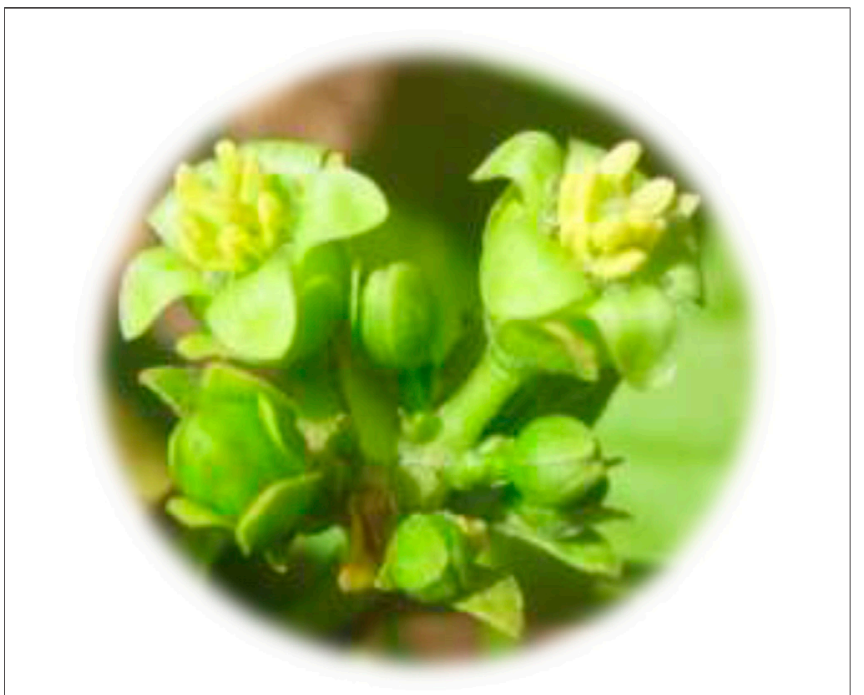

FIGURE 2 | Jatropha Curcas L flowers (Perumal and Sanmugam, 2015).

the Greek words "Jatros," which means "doctor," and "trophy," which means "food," and references to the plant's past medicinal uses (Kumar and Sharma, 2008). Jatropha Curcas is a dense shrub or small tree that may reach a height of 3-5 m (Figure 1). Under ideal circumstances, it may reach a height of $10 \mathrm{~m}$. It has $2 \mathrm{n}=22$ chromosomes and is a diploid species (Carels, 2009).

Despite having a native range that spans South and Central America, South-East Asia, Africa, and India the plant now has a pantropical distribution with distinct Jatropha Curcas seed provenances (Garnayak et al., 2008; Kumar and Sharma, 2011; Moser, 2011). Jatropha Curcas may thrive in a variety of rainfall conditions, from 250 to over 1,200 mm per year (Divakara et al., 2010). This plant can tolerate temperatures between 20 and $26^{\circ} \mathrm{C}$, as well as rich soil, proper drainage, and $\mathrm{pH}$ values between 5.0 and 6.5 (Katwal and Soni, 2003). This plant requires well-drained, well-aerated soils and thrives in low-nutrient, marginal soils, shedding its leaves during the dry season (Openshaw, 2000). Plantation areas of $2 \mathrm{~m} \times 2 \mathrm{~m}, 2.5 \mathrm{~m} \times 2.5 \mathrm{~m}$, and $3 \mathrm{~m} \times 3 \mathrm{~m}$, according to Heller, are adequate and generate higher fruit harvests (Heller, 1996). The second year of operation begins to produce fruit, and by the fourth or fifth year, the economic output has stabilised.

In Mexico, there are two sorts of genotypes: hazardous and non-toxic (Becker and Makkar, 1998). It's possible that the plant will survive for up to 50 years (Achten et al., 2010). It's a deciduous plant with a morphological discontinuity and an articulated growth habit. A primary taproot and four shallow lateral roots make up the root system (Abdelgadir and Van Staden, 2013). Smooth greenish-bronze bark and transparent latex cover the glabrous branches. Smooth, 5-lobed, heartshaped leaves, ten to $15 \mathrm{~cm}$ long, dark green, cordate or round, acute at the apex, cordate at the base, alternating, and dropping once a year (Nayak and Patel, 2010; Kamal et al., 2011). The flowers are borne in axillary clusters on a $3-5 \mathrm{~cm}$ tall stem with whole, lanceolate, or linear bracts that are highly pubescent and yellowish-green, and enormous glandular discs on the 


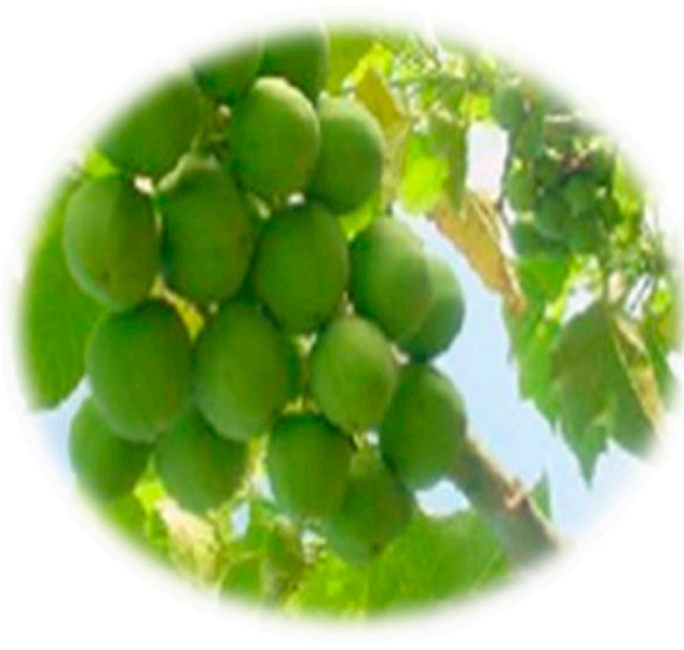

FIGURE 3 | Jatropha Curcas plant with fruit (Evangelista and Cermak, 2007).

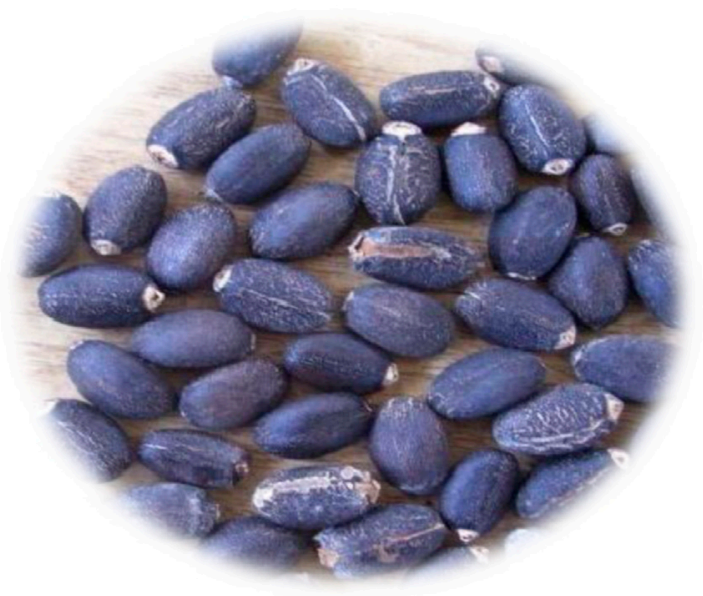

FIGURE 4 | Jatropha Curcas seeds with shells (Rao and Rao, 2013).

blooms (Figure 2) (Perumal and Sanmugam, 2015). 5 ovateelliptic sepals, less than $4 \mathrm{~mm}$ long, 5 oblong-obovate petals, 6-7 mm long, densely hairy inside, and eight stamens make up the male flower. Female flowers are $4 \mathrm{~mm}$ long, with loose oblong petals and bigger sepals (Raju and Ezradanam, 2002; Abdelgadir et al., 2009).

Jatropha Curcas oil production is expected to reach 1,590 kg/ ha (Vyas and Singh, 2007; Gui et al., 2008; Janaun and Ellis, 2010). Fruits are trilobite ovoid capsules with three cells and a length of 23-30 $\mathrm{mm}$ by a width of $28 \mathrm{~mm}$. The seeds of Jatropha Curcas have a thin shell and an oblong shape with a dark back colour (Dehgan, 2012). The mature Jatropha Curcas seeds are $212 \mathrm{~cm}$ in length and may easily be cracked to extract the oil. Toxins such as phorbol esters, curcin, trypsin inhibitors, lectins, and phytates are present in such high amounts in most provenances' blackish

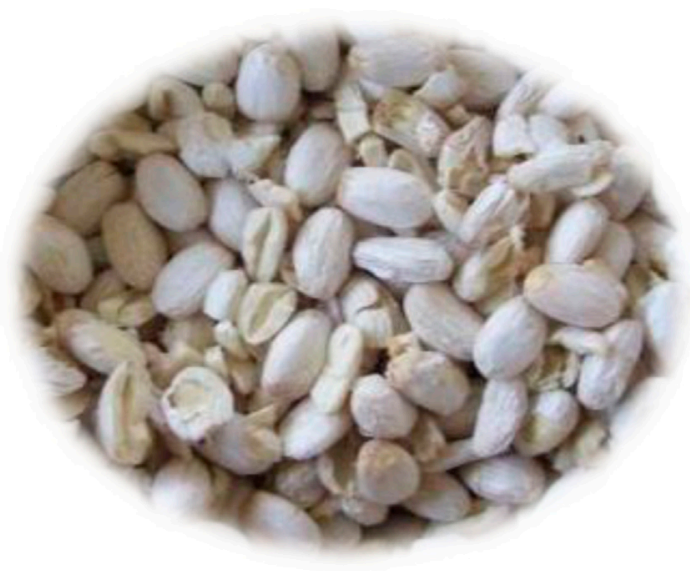

FIGURE 5 | Jatropha Curcas seeds (Rao and Rao, 2013).

seeds (Figure 3, Figure 4, Figure 5) that the seeds, oil, and seed cake are not for human consumption without detoxification (Raju and Ezradanam, 2002; Kumar and Sharma, 2011).

Plants of substantial economic importance in this family include:

(i) Roots: Manihot Esculenta (cassava)

(ii) Rubber: Hevea Brasiliensis

(iii) Nuts: Caryodendron Orinocense (tacay nut)

(iv) Vegetables: Sauropus Androgynous (katuk)

(v) Oils: Ricinus Communis Linn (castor bean); Aleurites spp. (tung trees)

(vi) Sapium Sebiferum (Chinese tallow tree)

(vii) Physic nut. Hydrocarbon: Euphorbia spp.

(viii) Medical: Croton spp.; Jatropha spp.

\section{JATROPHA OIL EXTRACTION METHODS}

Jatropha Curcas oil is stored in the fruit as triacylglycerol (TAG); to liberate these lipids, the cell wall must be weakened or disrupted. Lipid recovery from various organic sources may be accomplished using a variety of lipid extraction techniques. The type and oil content of lipid components varies. Many approaches are being used in order to improve the process by extracting the highest amount of oil from the Jatropha Curcas seed at the lowest possible cost (Mariana et al.). Mechanical extraction (cold press technique and expeller-pressed method) and solvent-based extraction were utilised in many developing nations to extract the oil content from the seeds (Soxhlet extraction method). Due to technological improvements in recent years, a few new technologies in oil extraction have been established, including supercritical fluid extraction, ultrasound-assisted extraction, and microwave-assisted extraction. Oil extraction techniques are intended to deliver high extraction yields and create highvalue meals by obtaining high-quality oil with minimum unwanted components. In the next part, the extraction process and its benefits and drawbacks will be examined in depth. The 

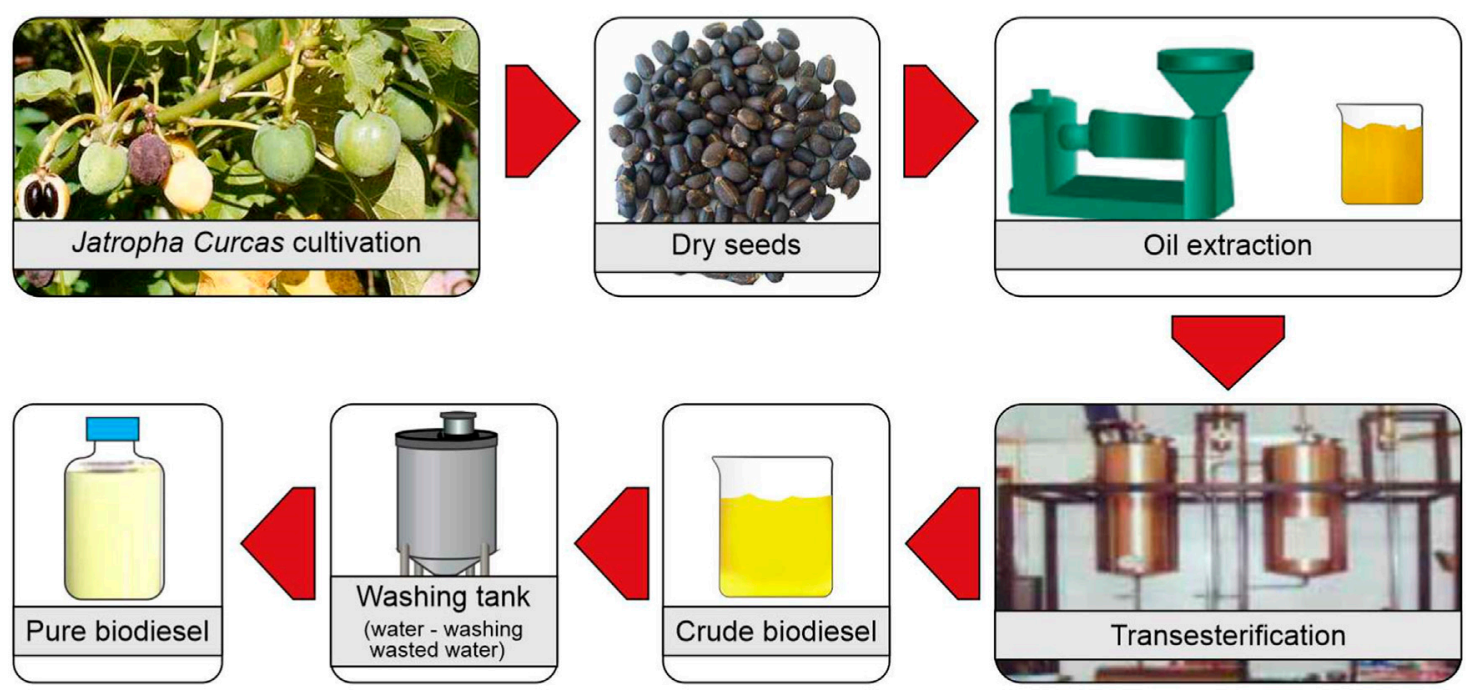

FIGURE 6 | Jatropha Curcas biodiesel production processes.

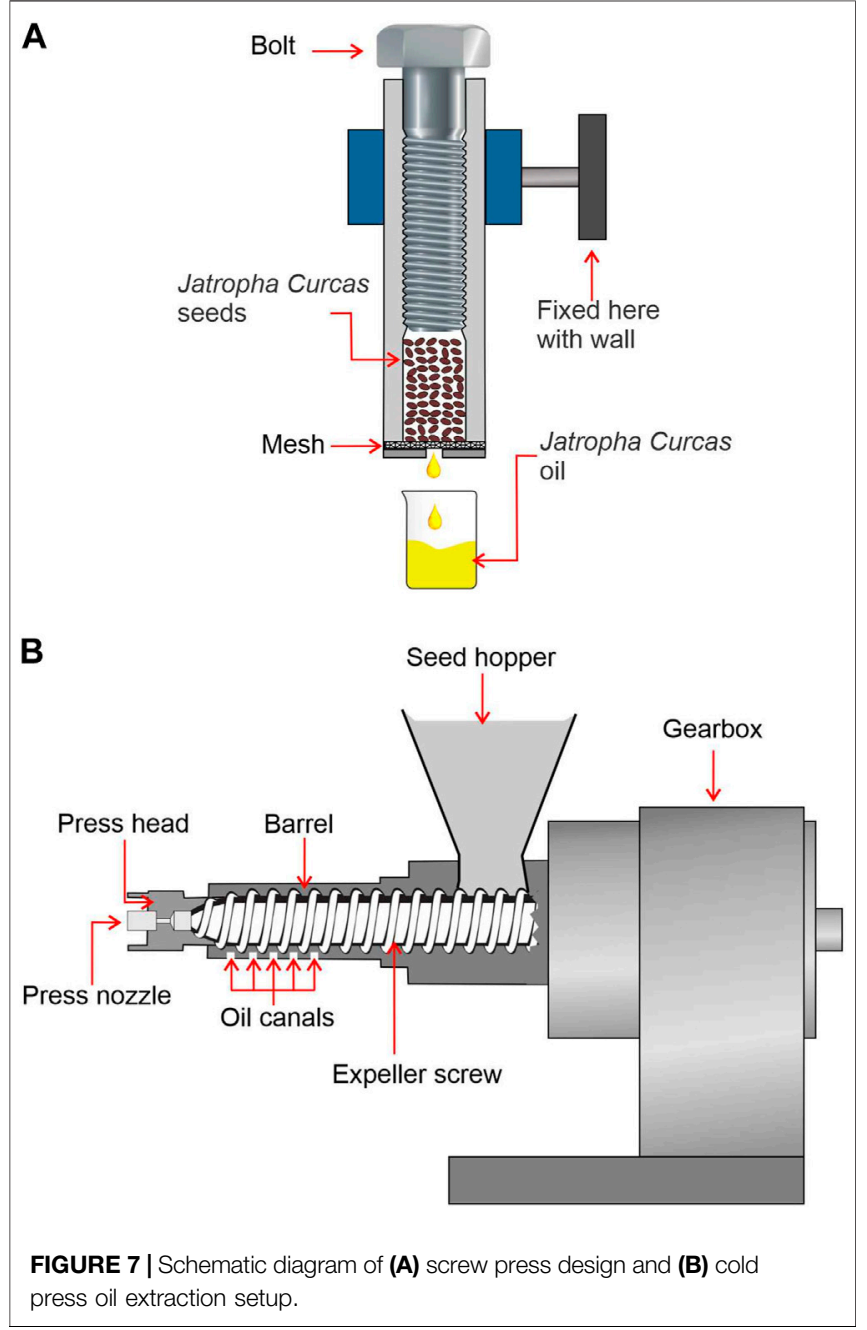

Jatropha Curcas biodiesel production processes is presented in Figure 6.

\section{Mechanical Extraction}

Mechanical pressing is a conventional oil recovery technology, and it has the lowest rate of oil recovery and is typically favoured by small businesses since it is less costly and safer than solvent extraction and requires less maintenance. Figure 7 shows a schematic representation of a screw press machine. A helical body (worm) that spins in a tight area creates the pressing force in the mechanical pressing technique, which may be operated by either hydraulic presses or screw presses (press chamber). The hydraulic presses were replaced with continuous screw presses, which required less labour. A vertical feeder and a horizontal screw with increasing body diameter progress along the length of the press to put pressure on the oilseeds. The barrel of the screw has slots along the length of it, allowing growing internal pressure to first release air and then drain the oil through the barrel. At the end of the screw, the de-oiled cake is discharged, and the Jatropha Curcas oil is collected in a trough underneath the screw (Romanić, 2020). The screw press's key benefit is that it can handle enormous amounts of Jatropha Curcas seed with little effort, and continuously oil extraction may be done. A screw press is a machine that extracts oil by pressing seeds and nuts through a chamber with high friction and pressure. There is no additional heat added to the process, but the seeds are squeezed using friction, which generates heat between 60 and $100^{\circ} \mathrm{C}$ (Ionescu et al., 2014). The oil will be extracted once the seeds have been crushed. The seeds will stay in the press to form a hard "brick" that may be used as animal feed. The cold-pressed technique involves pressing the seed using an oilseed press to generate coldpressed oil with less heat utilised or created during the process. To get the oil, the seed was put in the press and crushed by the machine. In comparison to an expeller press, the procedure may 
be carried out at a significantly lower temperature $\left(50^{\circ} \mathrm{C}\right)$ (Saleem and Ahmad, 2018). Prior to the pressing process, the oilseed materials are subjected to various pre-treatments such as washing, conditioning, heating, flaking, and dehulling in order to maximise the volume and quality of oil recovered from the raw material. In the past, significant attempts were made to increase the oil extraction efficiency of screw presses. As a result, the majority of researches concentrated on improving pressing process factors such as applied pressure, pressing temperature, and moisture conditioning of the supplied sample (Ofori-Boateng et al., 2012; Subroto et al., 2015).

Other advancements to oil screw presses were the design of the machines and the materials used in their manufacture. For Jatropha Curcas, Chapuis et al. (Chapuis et al., 2014) conducted pilot-scale research to determine the effects of seed pre-treatment (whole, crushed, and deshelled seeds), as well as screw press operating settings (shaft rotating speed and press cake output section). According to their findings, seed preparation affects the quality and efficiency of oil extraction. The intact seed is found to have high reproductivity, but crushed seeds and deshelled seeds created unstable pressing conditions (Chapuis et al., 2014). Yate et al. (Yate et al., 2020) performed research on the mechanical extraction of Jatropha Curcas using a screw press type expeller. Their research looked at the oil yield under various operating settings, including changing the extraction temperature, screw rotating speed, and diameter of the nozzle at the end of the press. With the maximum examined temperature $\left(90^{\circ} \mathrm{C}\right)$, the nozzle diameter is $11 \mathrm{~mm}$, and the rotating speed is $40 \mathrm{rpm}$, the highest yield was achieved (Yate et al., 2020). This mechanical screw oil extraction press may also be utilised for other feedstocks like Calophyllum Inophyllum, according to Bhuiya et al. (Bhuiya et al., 2020), who conducted their research to see how processing parameters affect extraction output. With a moisture percentage of $14.4 \%$, the kernels were able to provide roughly $78 \%$ of oil production. Mechanical screw presses are suitable for higher oil yield feedstocks since roughly $8-14 \%$ of the oil remaining in the cake and residual material. This approach is not ideal for low oil yield feedstock; instead, solvent extraction would be more appropriate.

\section{Solvent-Based Extraction (Soxhlet Extraction Method)}

Leaching is a solvent-based extraction method that involves extracting the soluble fraction (solute or leachate) from Jatropha Curcas seeds into a liquid solvent (Bhuiya et al., 2020). Chemical extraction has grown popular in the oil extraction business because of the high percentage of oil output and the expectation of producing high-quality oil. Due to their polar nature, different solvents may give varied oil yields when using the solvent extraction process. Oil extraction solvents such as hexane, propane, ethane, tetrahydrofuran (THF), ethanol, dichloromethane, methanol, and the methanol-water binary system were all widely employed (Haile et al., 2019; Zhang et al., 2019; Alrashidi et al., 2020). Even if there is great purity and high oil production by utilising solvent, there is still energy squandered throughout the lengthy extraction process. An

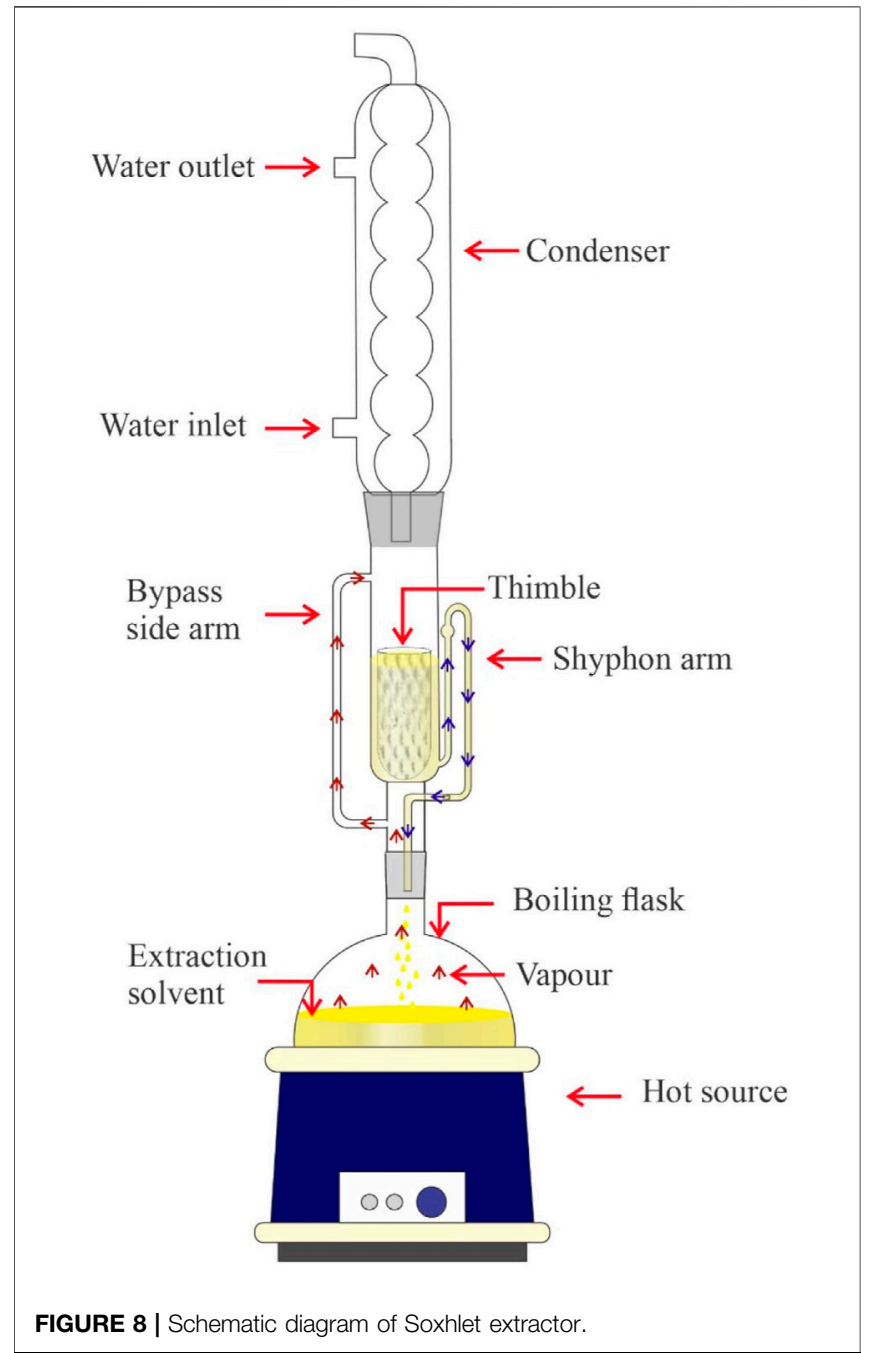

experiment used Soxhlet extraction to do a Response surface methodology optimisation analysis of crude oil. The solvent to seed ratio, reaction temperature, and extraction duration were the analytical parameters. The extraction was carried out using n-Hexane as the solvent, with solid-to-solvent ratios of 3:1, 5: 1 , and 7:1 (v/w) and three distinct extraction times of 4,5 , and $6 \mathrm{~h}$ (hrs). The reaction temperature varies between 60 and $70 \mathrm{C}$ (Jose et al., 2011). Another study used a solvent extraction approach on Calophyllum Inophyllum feedstock and found that extraction using solvent (hexane) yielded the best yield of $86.4 \%$, outperforming mechanical screw presses (Bhuiya et al., 2020). Alrashidi et al. (Alrashidi et al., 2020) tested the Soxhlet extraction technique for Nigella sativa $\mathrm{L}$ seed using several solvents. The results demonstrate that employing ethanol as a solvent yields the maximum oil yield $(40.2 \%)$, whereas the methanol-water combination yields the lowest oil yield (28.3\%). Rajeshwaran et al. (Rajeshwaran et al., 2020) used polar and non-polar solvents to extract oil from Prosopis Julifera feedstock for 3-8 h. They investigated the solid-tosolvent ratio, reaction time, and reaction temperature and reported that a solid-to-solvent ratio of $1: 9(\mathrm{w} / \mathrm{v})$ and a 


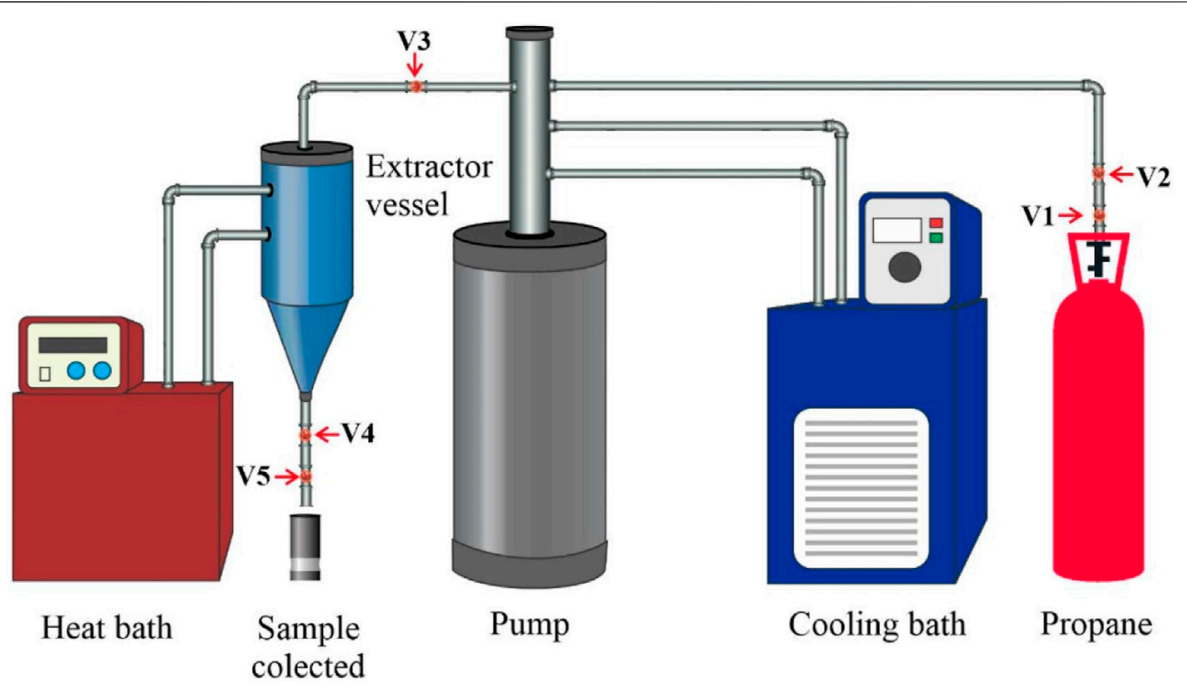

FIGURE 9 | The compressed propane system setup. Ball valves V1 and V2; needle valve V3; blockage valve V4; needle valve V5.

reaction temperature of $60 \mathrm{C}$ for $9 \mathrm{~h}$ yielded an optimum yield of $37 \%$. Haile et al. (Haile et al., 2019) reported that they investigated the oil extraction yield on Moringa Stenopeta seed collected from various locations using hexane and petroleum ether. The results show that petroleum ether is much more suitable for extracting these oils, producing $35.3-44.3 \%$ oil yield, whereas hexane produced $34.8-42.3 \%$ oil yield. Solvent extraction is a significantly more effective way of recovering oil from oilseeds than mechanical extraction since it involves dissolving oil by contacting oilseeds with a liquid solvent. The oilseed preparation, temperature, mode of operation, and equipment design all affect oil recovery efficiency. The oil and solvent combination separation is difficult with this approach, making it more appropriate for a small-scale manufacturing plant. A schematic diagram of the Soxhlet extractor is presented in Figure 8.

\section{Supercritical Fluid Extraction}

The supercritical fluid extraction (SCFE) method was offered as an alternative to traditional oil and oilseed processing. The essential oil sector is the most common use of this procedure. Solvents employed include ethanol, isopropyl alcohol, acetone, iso-hexane, n-hexane, propane, and other supercritical fluids, comparable to those used in the Soxhlet extraction procedure. Supercritical extraction with carbon dioxide $\left(\mathrm{SC}-\mathrm{CO}_{2}\right)$ is a method that uses carbon dioxide as a solvent above its critical pressure and temperature. It is suggested for edible applications in the food industry (Xiong and Chen, 2020). The $\mathrm{CO}_{2}$ used as a solvent in the supercritical fluid extraction procedure is readily removed from the Jatropha Curcas oil. After the oil has been extracted, the pressure in the system will be released, the $\mathrm{CO}_{2}$ will return to the gas phase, and the oil will be precipitated from the $\mathrm{CO}_{2}$-Jatropha Curcas oil combination. This eliminates the need for manual separation; nonetheless, whether $\mathrm{CO}_{2}$ is emitted or recycled is dependent on the SCFE's design. Other solvents, such as ethanol, hexane, and others, are more difficult to separate, and the finished product is usually not suitable for culinary use but is suitable for other industries. The yield, fatty acid profile, and bioactive components of Pachira Aquatica feedstock are studied in relation to the kind of pressurised fluid used and the extraction process parameters. When n-propane was used instead of $\mathrm{CO}_{2}$ as a co-solvent, greater oil yields were obtained. Although the yield achieved with propane extraction was lower than that obtained with Soxhlet extraction, the processing time was significantly reduced (30 min vs 16 h) (De Lara Lopes et al., 2020; Fetzer et al., 2021). Another study found that extracting spent coffee ground oil using high-pressure $\mathrm{CO}_{2}$ and ethanol as the solvent raised the extraction yield to $16 \%$ with the working parameter of ethanol and spent coffee ground ratio: $2: 1$, the temperature of $80^{\circ} \mathrm{C}$, $20 \mathrm{MPa}$, and extraction period of $25 \mathrm{~min}$ (Haile et al., 2019). Coffee oil may also be extracted from wasted coffee grounds using Norflurane as a solvent at pressures ranging from 5 to 11 bar. For $75-285 \mathrm{~min}$ of extraction, the oil recovery efficiency is around 92\% (Cante et al., 2020). Cumaru seed oil extractions utilising propane at subcritical temperatures were carried out using a piece of improvised laboratory-scale equipment, as shown in Figure 9 (Fetzer et al., 2020). Temperature $\left(20,40,60^{\circ} \mathrm{C}\right)$, pressure $(2,6$, $10 \mathrm{MPa})$, and average particle size $(2,1.7,1.0,0.5 \mathrm{~mm})$ of Cumaru seed were all altered in the study, and the findings revealed that $98 \%$ of the total oil contained in the seeds could be extracted at $60^{\circ} \mathrm{C}, 10 \mathrm{MPa}$, and $0.5 \mathrm{~mm}$. According to the research, compressed propane supplied much more unsaturated fatty acids than Soxhlet extraction using $\mathrm{n}$-hexane due to the fatty acid profile (Fetzer et al., 2020).

\section{Ultrasound-Assisted Extraction}

Ultrasound-assisted extraction (UAE) is a technique for extracting plant components that might possibly be used to extract Jatropha Curcas oil. In comparison to previous methods, this technique allows for the extraction of natural substances in shorter timeframes, with greater reproducibility, less solvent consumption, and easier procedures. The effect of cavitation, which causes microbubbles to implode and plant 


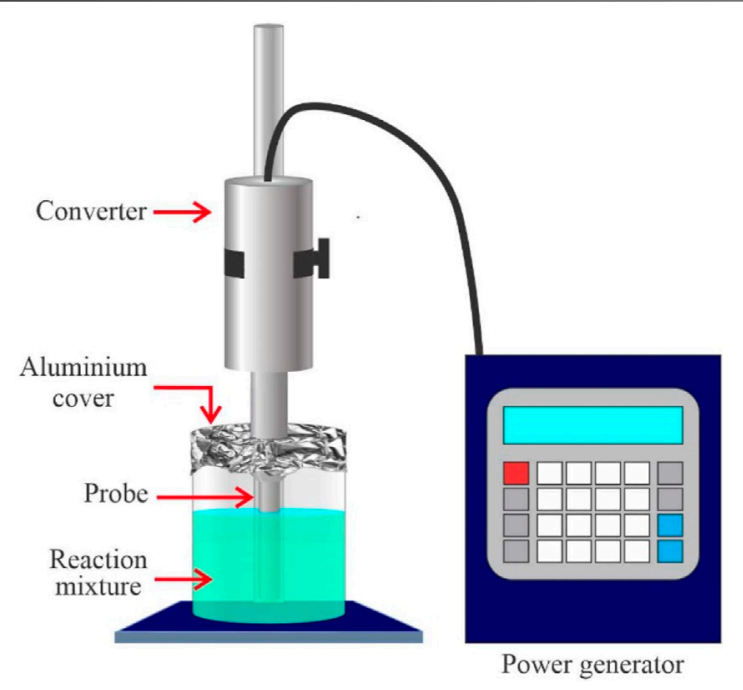

FIGURE 10 | Experimental setup for ultrasound-assisted in situ esterification.

tissue cell walls to burst, is connected to the mechanism of action of ultrasound (Suganya et al., 2014). This damage accelerates the mass transfer of the solvent to the matrix's internal area and the soluble components to the solvent, creating turbulence and solvent penetration into the plant matrix, as well as the release of intracellular material. In an ultrasonic bath, in-direct contact ultrasonic extraction was performed. Stevanato and Silva used ultrasound-assisted extraction (UAE) and ethanol as the solvent in their study to extract oil from radish seed (RSO). The temperature had the greatest influence on oil extraction, with a maximum oil yield of $25 \%$ reached $60^{\circ} \mathrm{C}$, a solvent to seed ratio of $12 \mathrm{ml} \mathrm{g1}$, and a 60-min extraction time (Stevanato and $\mathrm{Da}$ Silva, 2019). When compared to the UAE approach, the oil output is reduced by over $50 \%$ without the use of ultrasonic. Ultrasound is said to be capable of performing an in-situ procedure, in which extraction and transesterification are both accomplished at the same time. Tan et al. did a similar experiment to manufacture biodiesel from Jatropha Curcas seed using ultrasonic irradiation. According to their findings, extraction efficiency is about $84 \%$ when employing $5 \%$ vol $\mathrm{H}_{2} \mathrm{SO}_{4}$ with a $3: 1$ solvent-to-methanol volume ratio, a $60 \%$ ultrasonic amplitude, and a reaction duration of $150 \mathrm{~min}$ with a low acid value of $5.3 \mathrm{mg} \mathrm{KOH} / \mathrm{g}$ (Tan et al., 2019; Zhang et al., 2019). The experimental setup for ultrasoundassisted surgery is shown in Figure 10. Suganya et al. used ultrasonic irradiation to extract and convert the oil from macroalgae Enteromorpha compressa biomass utilising tetra hydro furan (THF) as a cosolvent and $\mathrm{H}_{2} \mathrm{SO}_{4}$ as a catalyst to extract and convert the oil into biodiesel. The parameters used were $30 \mathrm{vol} \% \mathrm{THF}$ as a co-solvent, $10 \mathrm{wt} \% \mathrm{H}_{2} \mathrm{SO}_{4}, 5.5: 1$ methanol to algal biomass ratio, and $600 \mathrm{rpm}$ mixing intensity at $65^{\circ} \mathrm{C}$ for 90 min of ultrasonic irradiation duration, yielding a maximum biodiesel production of 98.89\% (Suganya et al., 2014). Many people believe that ultrasonic irradiation may manufacture the oil's end product in one step (in-situ), saving the solvent and catalyst needed in the intermediate steps.

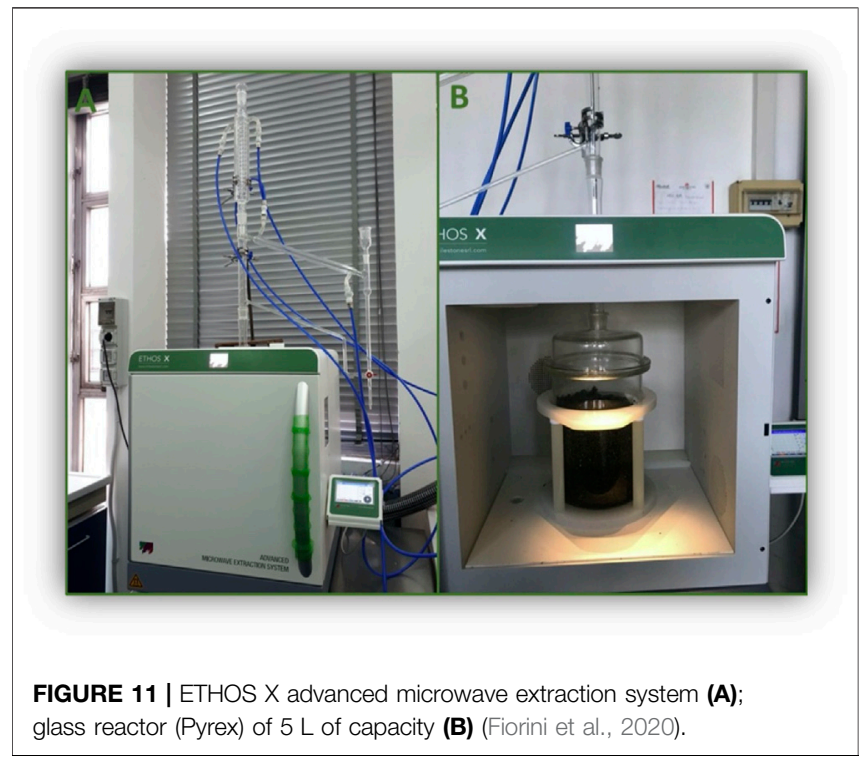

\section{Microwave-Assisted Extraction}

Suganya et al. used ultrasonic irradiation to extract and convert the oil from macroalgae Enteromorpha Compressa biomass utilising tetra hydro furan (THF) as a cosolvent and $\mathrm{H}_{2} \mathrm{SO}_{4}$ as a catalyst to extract and convert the oil into biodiesel. The conditions were $30 \mathrm{vol} \% \mathrm{THF}$ as a co-solvent, $10 \mathrm{wt} \% \mathrm{H}_{2} \mathrm{SO}_{4}$, 5.5:1 methanol to algal biomass ratio, and $600 \mathrm{rpm}$ mixing intensity at $65^{\circ} \mathrm{C}$ for $90 \mathrm{~min}$ of ultrasonic irradiation time, providing a maximum biodiesel output of $98.89 \%$ (Suganya et al., 2014). Many people believe that ultrasonic irradiation may manufacture the oil's end product in one step (in-situ), saving the solvent and catalyst needed in the intermediate steps (Tsubaki et al., 2019). Fiorini et al. employed a microwaveassisted extraction technique to extract Cannabis Sativa L. oil, as shown in Figure 11. In an optimisation study using a central composite design, the microwave irradiation power $(\mathrm{W} / \mathrm{g})$, extraction time (minutes), and water delivered to the plant matrix after moistening (\%) were investigated (CCD) (Fiorini et al., 2020). Based on the optimisation results, the maximum oil yield was $0.15 \%$ (Fiorini et al., 2020). Ibrahim et al. extract oil from the non-edible Hura Crepitans seed, which is native to Nigeria. Hura Crepitans is said to be rich in oil, with oil content ranging from 36 to $64 \%$. Extraction parameters such as extraction duration (5-15 min), heating power $(180-540 \mathrm{~W})$, solid/solvent ratio (1:10-1:40), and solvent type were optimised (ethyl acetate, n-hexane and acetone). Using an extraction period of $5 \mathrm{~min}$, the heating power of $180 \mathrm{~W}$, a solid/solvent ratio of $1: 40$, and ethyl acetate as the working solvent, an optimal extraction yield of $72.2 \mathrm{wt} \%$ was attained (Ibrahim et al., 2019). Kumar et al. (Kumar et al., 2018) used a redesigned and modified microwave from a commercial microwave to extract oil from Pongamia Pinnata seeds. Microwave power levels of 300, 600, and $900 \mathrm{~W}$ were used to extract oil, with the results indicating that the optimal conditions were $600 \mathrm{~W}$ for $14 \mathrm{~min}$ with a yield of $20 \%$. 
TABLE 1 | The advantages and disadvantages of extraction.

\begin{tabular}{|c|c|c|c|}
\hline Extraction methods & Advantages & Disadvantages & References \\
\hline Mechanical extraction & $\begin{array}{l}\text { - When compared to hand pressing, it has a } \\
\text { higher oil extraction efficiency (68-80\%). } \\
\text { - In mechanical extraction, pre-heating may } \\
\text { boost efficiency by up to } 91 \% \text {. } \\
\text { - No oil contamination with solvent } \\
\text { - One of the cheapest extraction process }\end{array}$ & $\begin{array}{l}\text { - Labour and time-intensive } \\
\text { - Only applicable for a limited type of feedstock. } \\
\text { - Less oil production }\end{array}$ & $\begin{array}{l}\text { Hayyan et al. (2022) } \\
\text { Ayoub et al. (2021) } \\
\text { Tsubaki et al. (2019) } \\
\text { Yate et al. (2020) }\end{array}$ \\
\hline $\begin{array}{l}\text { Solvent-based extraction } \\
\text { (Soxhlet extraction method) }\end{array}$ & $\begin{array}{l}\text { - With a less quantity of solvent, a large amount } \\
\text { of plant material may be removed. } \\
\text { - The solvent can be used repeatedly. } \\
\text { - Does not require filtration after extraction. } \\
\text { - Does not depend upon the type of matrix. } \\
\text { - A very simple technique. } \\
\text { - Several extractions can be conducted in } \\
\text { parallel. } \\
\text { - able to extract more sample mass than other } \\
\text { techniques. } \\
\text { - easy continuous operation and ease of } \\
\text { automation. }\end{array}$ & $\begin{array}{l}\text { - If the plant material heat-labile chemicals, the danger of } \\
\text { thermal destruction of certain compounds will occur } \\
\text { occasionally. } \\
\text { - The extraction procedure takes a long time and requires } \\
\text { a lot of effort. } \\
\text { - The method enables the manipulation of a small number } \\
\text { of variables. } \\
\text { - The quantity of time and solvent required to result in a } \\
\text { considerable volume of solvent. } \\
\text { - Because of the toxic solvent, it is not environmentally } \\
\text { friendly. } \\
\text { - Unwanted products and other contaminants should be } \\
\text { dissolved. }\end{array}$ & $\begin{array}{l}\text { Rasul, (2018) } \\
\text { Ayoub et al. (2021) } \\
\text { Haile et al. (2019) } \\
\text { Zhang et al. (2019) } \\
\text { Guo and Lee, (2011) } \\
\text { Cunha and Fernandes, } \\
\text { (2018) } \\
\text { Zhang et al. (2018) }\end{array}$ \\
\hline Supercritical fluid extraction & $\begin{array}{l}\text { - The approach is suitable for thermal labile } \\
\text { chemicals and is also eco-friendly. } \\
\text { - Supercritical conditions and increased solvent } \\
\text { solubility result in a greater extraction rate. } \\
\text { - Because CO2 is more readily available and } \\
\text { inflammable, it is a less expensive solvent to } \\
\text { utilise. } \\
\text { - A less amount of solvent is used. } \\
\text { - Extraction time is reduced. }\end{array}$ & $\begin{array}{l}\text { - A significant of investment cost. } \\
\text { - High pressure and temperature are required. } \\
\text { - Possibilities of impurities } \\
\text { - Compounds that are thermally labile should not be used. } \\
\text { - There are several parameters to optimise. } \\
\text { - Technical complexity is increasing. } \\
\text { - Losses might be variable. } \\
\text { - Possibility clogging of the system is a. }\end{array}$ & $\begin{array}{l}\text { Ajila et al. (2011) } \\
\text { Ayoub et al. (2021) } \\
\text { Xiong and Chen, (2020) } \\
\text { Zougagh et al. (2004) } \\
\text { Janda et al. (1993) } \\
\text { Sairam et al. (2012) }\end{array}$ \\
\hline $\begin{array}{l}\text { Ultrasound-assisted } \\
\text { extraction }\end{array}$ & $\begin{array}{l}\text { - Environmental friendly method } \\
\text { - Can replace the solvents with generally } \\
\text { recognized as safe solvents } \\
\text { - Extraction efficiency is high. } \\
\text { - Extraction time is shorter. } \\
\text { - Thermo labile chemicals benefit from this. } \\
\text { - Process that saves energy. } \\
\text { - More time may be spent without changing the } \\
\text { molecular structure. }\end{array}$ & $\begin{array}{l}\text { - The dispersion of ultrasonic energy is not uniform. } \\
\text { - The use of ultrasonic waves causes the internal } \\
\text { structure of chemicals in the oil to degrade. } \\
\text { - A large amount of solvent is required. }\end{array}$ & $\begin{array}{l}\text { Ajila et al. (2011) } \\
\text { Ayoub et al. (2021) } \\
\text { Carreira-Casais et al. (2021) } \\
\text { Zougagh et al. (2004) } \\
\text { Naziri et al. (2016) }\end{array}$ \\
\hline $\begin{array}{l}\text { Microwave-assisted } \\
\text { extraction }\end{array}$ & $\begin{array}{l}\text { - The extraction time is shorter and higher } \\
\text { extraction yield } \\
\text { - The use of microwave heating to extract oil } \\
\text { eliminates } \mathrm{CO}_{2} \text { emissions. } \\
\text { - When compared to traditional heating, just a } \\
\text { fraction of the energy is used. } \\
\text { - Reduce the amount of solvent use. }\end{array}$ & $\begin{array}{l}\text { - When the solvent or desired substance is non-polar or } \\
\text { volatile, this approach is ineffective. } \\
\text { - High maintenance cost for industrial scale. } \\
\text { - No high temperature solution. } \\
\text { - The addition of solvent is not permitted in this single } \\
\text { step. }\end{array}$ & $\begin{array}{l}\text { (Danlami et al., 2014) } \\
\text { (Ayoub et al., 2021) } \\
\text { Gutiérrez-Escobar et al. } \\
\text { (2021) } \\
\text { Delazar et al. (2012) } \\
\text { Jain et al. (2009) }\end{array}$ \\
\hline
\end{tabular}

\section{Comparison of Oil Extraction Methods}

As previously discussed, several oil extraction techniques have been extensively employed; this section will go through the advantages and disadvantages of each process. The type of feedstock extracted, the cost and the environmental impact of the material used for extractions are frequently taken into account when choosing an extraction process. A part od the rude oil as main product, the biomass waste are the major byproducts of jatropha oil production. Biomass by-products are often discarded into the environment, however, they may be utilised as resin, fertiliser, adsorbent, briquettes, and bioactive compost (Primandari et al., 2018). Based on application, cost, efficiency, and environmental dangers, the advanced of current oil extraction methods have been explored in depth. Therefore, to a get a clear idea on this issue, a critical comparison of several extraction methods are presented in Table 1.

\section{CHARACTERISTICS OF JATROPHA CURCAS OIL AND BIODIESEL}

The properties of vegetable oils significantly differ from diesel fuel, however with an appropriate treatment Jatropha Curcas oil can achieve a comparable property as biodiesel and may be used in diesel engines in buses, lorries, cars and other vehicles. It has been successfully tested and has excellent stability at low 
temperatures, making it an interesting option for use in jet fuels. A study looked at the chemical composition, toxic/anti-metabolic components, and impact of different treatments on their levels in four Mexican Jatropha Curcas provenances (Herrera et al., 2006). The authors looked at the proximate composition, total soluble sugars, and starch content of Jatropha Curcas seed kernel meal from a range of agroclimatic zones in Mexico. The crude protein (31-35\%), and fat levels of the samples differed somewhat (55-58\%). Coatzacoalcos has a crude protein percentage of $62.0 \%$, whereas Castillo de Teayo has a crude protein value of $65.0 \%$. The crude protein content of the samples was greater in several treatments. The fibre level of Jatropha Curcas meals was lower than that of soybean meal in their research but equivalent to other seed provenances from Cape Verde (4.7\%), Senegal (5.6\%), Burkina Faso (5.3\%), India (4.5\%), and Nicaragua (4.5\%). (4.5\%). $4.5 \% 3.8 \%$ point (pp. 86, 87). Whole kernels had comparable gross energy content $(31.1-31.6 \mathrm{MJ} / \mathrm{kg})$. Both total soluble sugars and starch content were less than $6 \%$. The researchers used previously available information to compare the fatty acid composition of three Jatropha Curcas seed oils. All of the oil samples included oleic, linoleic, palmitic, and stearic fatty acids. Oleic acid was the most common fatty acid in the Veracruz samples, whereas linoleic acid was the most frequent fatty acid in the Morelos samples. This variation might be due to soil and climatic conditions. According to the study, unsaturated fatty acids make up the majority of the oil (oleic and linoleic acid). The results are quite comparable to those published earlier for Jatropha Curcas seed provenances from other countries (Banerji et al., 1985; Nasir et al., 1988; Gübitz et al., 1999).

The most prevalent fatty acid in crude Jatropha Curcas oil (CJCO) is oleic $(44.5 \%)$, followed by linoleic $(35.4 \%)$, palmitic (13.1\%), and stearic (13.1\%), 5.8\% of the population. Because it contains $80.9 \%$ unsaturated fatty acids, CJCO has outstanding low-temperature properties (oleic and linoleic acids). In crude Calophyllum Inophyllum oil (CCIO), unsaturated fatty oleic (46.1\%) and linoleic acid (24.7\%) are discovered in higher quantity than saturated fatty palmitic acids (14.7\%) and stearic acid (13.2\%). In addition, crude Calophyllum Pentandra oil (CCPO) contains $39.7 \%$ linoleic acid, $19.2 \%$ palmitic acid, and $18.5 \%$ malvaloyl acid. Sarin et al., and Abdullah et al., respectively, reported similar $\mathrm{CJCO}, \mathrm{CCIO}$, and $\mathrm{CCPO}$ composition findings (Abdullah et al., 2010; Sarin et al., 2010). Emil et al. (Emil et al., 2010) was extracted oil from Jatropha Curcas seeds taken from Malaysia, Indonesia, and Thailand, and the fatty acid content (FAC) was determined using gas chromatography (GC). They discovered that oleic acid (42.4-48.8\%) and linoleic acid (28.8-34.6\%) are the most abundant fatty acids in Jatropha Curcas oil. Saturated fatty acids like palmitic and stearic acid have molecular weights of 13.25-14.5 and 7-7.7\%, respectively. Table 2 presents FAC of Jatropha Curcas oil by various studies.

Numerous researchers investigated the physicochemical and thermal characteristics of Jatropha Curcas oil. For example, Mohammed-Dabo et al. (Mohammed-Dabo et al., 2012) evaluated the fatty free acid (FFA) content, viscosity, calorific value, acid, iodine, saponification parameters, and cetane number of Nigerian Jatropha Curcas seed oil. Table 3 shows the key physicochemical characteristics of raw Jatropha Curcas oil provided by important studies.

The characteristics of Jatropha Curcas biodiesel are crucial since they define the fuel's ultimate attributes. Vegetable oil's increased viscosity is a key drawback when used as a diesel engine fuel. The viscosity of biodiesel is reduced when it is converted. The fatty acid content of biodiesel is closely related to its characteristics. The structural fatty acid content of non-edible oil, which has a substantial number of double carbon chains, affects biodiesel physicochemical qualities such as cetane number, oxidation stability, the heat of combustion, and viscosity (Atabani et al., 2013). These properties indicate the quality of the fuel. The kinetic viscosity of the fuel determines its flow, spray, and atomisation properties. High viscosity reduces spray and atomisation and increases fuel consumption thus less viscosity is conducive for better performance (Arbab et al., 2013; Kuti et al., 2013). High density creates high viscosity, which causes inefficient combustion, poor engine performance, and poor emission characteristics (Alptekin and Canakci, 2009; Arbab et al., 2013). Cetane No. (CN) is connected to ignition delay time, or the interval between fuel injection and ignition. A greater $\mathrm{CN}$ causes a shorter ignition delay. For $\mathrm{CI}$ engine fuel, a higher $\mathrm{CN}$ is desired (Razak et al., 2021). A fuel's heating value is the amount of heat created during burning per unit of fuel. Fuel with a higher heating value is preferred since it helps combustion and increases engine performance (Arbab et al., 2013). According to Pinzi et al. (Pinzi et al., 2009) a longer carbon chain length results in a greater heating value, which has a significant impact on biodiesel's cold flow properties. Table 4 shows a comparison of physicochemical properties of Jatropha Curcas biodiesel and diesel and corresponding biodiesel standard in Europe.

The effectiveness of centrifugal separators to remove pollutants is influenced by their density. The centrifugal cleaning process is driven by the density differential between the impurities in the fuel and the fuel oil itself. Amidst this comparison, biodiesel produced from Jatropha Curcas oil showed a density of $879 \mathrm{~kg} / \mathrm{m}^{3}$ (Foidl et al., 1996) $876.2 \mathrm{~kg} / \mathrm{m}^{3}$ (Sarin et al., 2007), $876.2 \mathrm{~kg} / \mathrm{m}^{3}$ (Dharma et al., 2017), respectively, which are fulfilling the requirement the limits stated by European legislation. Viscosity, which is also an essential attribute of lubricants, is one of the most significant fuel qualities of biodiesel and diesel fuel generated from petroleum. Various biodiesel and diesel standards specify allowable kinematic viscosity ranges. The viscosity of biodiesel must be below $5 \mathrm{~mm}^{2} / \mathrm{s}$ and $6 \mathrm{~mm}^{2} / \mathrm{s}$ as required by EN ISO 3104 and D445, respectively, to achieve complete combustion with minimum coke deposit in the engine. Jatropha curcas has a viscosity of $4.84 \mathrm{cSt}$ (Foidl et al., 1996), $4.16 \mathrm{cSt}$ (Sarin et al., 2007) and 4.57 cSt (Dharma et al., 2017), respectively. All viscosity met the requirement stipulated in the ASTM D445 method. Although the actual viscosity of biodiesel depends on the fatty acid composition of the oil or fat from which it is made and also on the extent of oxidation and polymerization of the biodiesel. The lowest temperature at which a fuel generates enough vapour to induce ignition and flame production is known as the flash point. The flash point of biodiesel is greater than that of normal diesel. Furthermore, biodiesel's flash point criteria is greater than 
TABLE 2 | Fatty acid composition of the Jatropha Curcas oil.

Fatty acids (no of carbon atoms:degree of unsaturation)

\section{Fatty acid relative composition (\%) in oil}

Emil et al. (2010) Foidl et al. (1996) Sarin et al. (2007) Ashraful et al. (2014) Kumar and Sharma,
(2011)

Decanoic acid (10:0)

Myristic acid (14:0)

Palmitic acid (16:0)

Palmitoleic acid (16:1)

Stearic acid (18:0)

Oleic acid (18:1)

Linoleic acid (18:2)

Linolenic acid (18:3)

Arachidic acid (20:0)

Behenic acid (22:0)
Emil et al. (2010) $\quad$ Foidl et al. (1996) Sarin et al. (2007) Ashraful et al. (2014)

$\begin{array}{cc}- & 0.1 \\ 0.1 & 0.1 \\ 13.2-14.5 & 13.6-15.1 \\ 0.6-0.7 & 0.8-0.9 \\ 7.0-7.7 & 7.1-7.4 \\ 42.4-48.8 & 34.3-44.7 \\ 28.8-34.6 & 31.4-43.2 \\ 0.1-0.2 & 0.2-0.3 \\ 0.2-0.3 & 02 .-0.3 \\ - & 0.2\end{array}$

-

0.2

-
-
14.2
1.4
6.9
43.1
34.4
-
-
-

$-$

15.6

$-$

9.7

40.8

32.1

0.4

\begin{tabular}{|c|c|c|c|c|c|}
\hline Parameter & $\begin{array}{l}\text { Emil et al. } \\
\qquad(2010)\end{array}$ & $\begin{array}{l}\text { Bilal et al. } \\
\text { (2013) }\end{array}$ & $\begin{array}{l}\text { Mohammed-Dabo et al. } \\
\qquad(2012)\end{array}$ & $\begin{array}{l}\text { Foidl et al. } \\
\qquad(1996)\end{array}$ & $\begin{array}{c}\text { Samniang et al. } \\
(2014)\end{array}$ \\
\hline$\% F F A$ & $1.69-9.20$ & 14.6 & 14.8 & $0.29-1.27$ & - \\
\hline lodine value & $92.53-107.57$ & - & 100.56 & $95.2-106.6$ & 84.2 \\
\hline Saponification value & 193.55-216.09 & 198.76 & 202.34 & $190.1-192.4$ & 199.2 \\
\hline Density $\left(\mathrm{kg} / \mathrm{m}^{3}\right)$ & $902.4-909.5$ (at $\left.20^{\circ} \mathrm{C}\right)$ & 920.4 & 874 & 920 & - \\
\hline Kinematic Viscosity (cSt) & 39.20-53.94 (at $40^{\circ} \mathrm{C}$ ) & 66.74 & - & $37-38.8\left(\right.$ at $\left.30{ }^{\circ} \mathrm{C}\right)$ & 33.55 (at $40{ }^{\circ} \mathrm{C}$ ) \\
\hline Acid value (mg KOH/g) & - & 29.06 & 29.6 & 0.92 & 7.0 \\
\hline
\end{tabular}

TABLE 4 | Fuel properties comparison Jatropha Curcas biodiesel and mineral diesel and corresponding biodiesel standard for Europe.

\begin{tabular}{|c|c|c|c|c|c|}
\hline Properties & $\begin{array}{c}\text { Jatropha Curcas } \\
\text { Biodiesel (Foidl } \\
\text { et al., 1996) }\end{array}$ & $\begin{array}{l}\text { Jatropha Curcas } \\
\text { biodiesel (Sarin } \\
\text { et al., 2007) }\end{array}$ & $\begin{array}{c}\text { Jatropha Curcas } \\
\text { biodiesel (Dharma } \\
\text { et al., 2017) }\end{array}$ & Mineral Diesel & $\begin{array}{c}\text { EN } 14214 \\
\text { (Tsoutsos et al., } \\
\text { 2019) }\end{array}$ \\
\hline Density $\left(\mathrm{kg} / \mathrm{m}^{3}\right)$ at $15{ }^{\circ} \mathrm{C}$ & 879 & - & 876.2 & $840 \pm 1.732$ & 860-900 \\
\hline Kinematic Viscosity at $40{ }^{\circ} \mathrm{C}$ (cSt) & 4.84 & 4.16 & 4.57 & $2.44 \pm 0.27$ & $3.4-5.0$ \\
\hline Pour Point $\left({ }^{\circ} \mathrm{C}\right)$ & $3 \pm 1$ & - & 2 & $6 \pm 1$ & N.A. \\
\hline Flash Point $\left({ }^{\circ} \mathrm{C}\right)$ & 191 & 163 & 125.5 & $71 \pm 3$ & Min. 101 \\
\hline Conradson Carbon residue (\%, w/w) & 0.01 & $<0.01$ & - & $0.1 \pm 0.0$ & Max. 0.05 \\
\hline Oxidation stability (h) & - & 3.23 & 14.01 & - & Min. $8 \mathrm{~h}$ \\
\hline Acid value (mg KOH/gm) & 0.24 & 0.48 & 0.46 & - & $\operatorname{Max} 0.5$ \\
\hline Sulphated ash (\%, w/w) & 0.014 & 0.002 & & $0.01 \pm 0.0$ & Max. 0.02 \\
\hline Calorific Value (MJ/kg) & 38.5 & - & 39.46 & 45.343 & - \\
\hline Sulphur $(\%$ w/w) & $<0.001$ & 0.004 & - & 0.25 & Max. 0.05 \\
\hline Carbon (\% w/w) & 77.1 & - & - & 86.83 & - \\
\hline Hydrogen (\% w/w) & 11.81 & - & - & 12.72 & - \\
\hline Oxygen (\% w/w) & 10.97 & - & - & 1.19 & - \\
\hline Cetane No. & $51-52$ & 57.1 & 59 (Cetane index) & $48-56$ & Min 51 \\
\hline Free glycerol (\% mass) & 0.015 & 0.01 & & - & Max 0.020 \\
\hline Total glycerol (\% mass) & 0.088 & 0.02 & & - & $\operatorname{Max} 0.250$ \\
\hline
\end{tabular}

that of diesel requirements. Biodiesel has a flash point of $150^{\circ} \mathrm{C}$ on average, while diesel fuel has a flash point of $55^{\circ} \mathrm{C}-66^{\circ} \mathrm{C}$ (Tat and Van Gerpen, 1999). FP was measured through EN ISO 3679 and ASTM D93. The flash point of the Jatropha Curcas Biodiesel was $191^{\circ} \mathrm{C}$ (Foidl et al., 1996), $163^{\circ} \mathrm{C}$ (Sarin et al., 2007), $125.5^{\circ} \mathrm{C}$ (Dharma et al., 2017) respectively, which is slightly lower than palm biodiesel $\left(182.5^{\circ} \mathrm{C}\right)$ but higher than CI biodiesel $\left(123.5^{\circ} \mathrm{C}\right)$, the reported flash point is still in the range stipulated in both test method. Calorific value is defined as the amount of heat emitted by a fuel when it is entirely burned and measured at a constant volume or constant pressure, with the hot gas cooled to its original temperature (Sharudina et al., 2018). Based on EN 14213 , the calorific value should be higher than $35 \mathrm{MJ} / \mathrm{kg}$. The calorific value was $38.5 \mathrm{MJ} / \mathrm{kg}$ (Foidl et al., 1996) and $39.46 \mathrm{MJ} / \mathrm{kg}$ (Dharma et al., 2017). The acid number (AN) is one of the analytical parameters usually employed to evaluate the quality of biodiesel. It represents the corrosive potential of biodiesel, which can reduce the lifetimes of fuel tanks and vehicle engines. The 
ASTM D 6751 biodiesel acid-number limit was harmonized with the European biodiesel value of 0.50. ASTM D 664 is the standard reference method for measuring the acid number of both ASTM biodiesel and petroleum-derived diesel. The existing literature revealed Jatropha Curcas has a near the borderline of $0.24 \mathrm{mg}$ $\mathrm{KOH} / \mathrm{g}$ (Foidl et al., 1996), $0.48 \mathrm{mg} \mathrm{KOH/g}$ (Sarin et al., 2007) and $0.38 \mathrm{mg} \mathrm{KOH} / \mathrm{g}$ (Dharma et al., 2017), respectively. Oxidation stability is the important property of fatty acid methyl esters and affects biodiesel primarily during extended storage. Biodiesel tends to be less resistant to oxidation than petroleum diesel. Thus, the higher the unsaturated chain of fatty acids, the lower its stability. The oxidation process was initiated with peroxides, forming a volatile organic compound such as aldehydes and ketones. The minimum induction time according to ASTM D6751 is $3 \mathrm{~h}$. Jatropha Curcas exhibits an oxidation time of $3.23 \mathrm{~h}$ (Sarin et al., 2010), and $14.01 \mathrm{~h}$ (Dharma et al., 2017) shows superior oxidation stability. It can be shown that the stability of biodiesel is strongly influenced by the makeup of unsaturated esters. Polyunsaturated esters are much more susceptible to oxidation than saturated or monounsaturated esters.

\section{ENGINE PERFORMANCE AND EMISSION OF USING JATROPHA CURCAS BASED BIODIESEL}

Biodiesel fuels have a greater oxygen concentration, they burn more efficiently (Elkelawy et al., 2019). To evaluate engine performance, the researchers usually look at 1) engine torque, 2) brake power (BP), 3) brake specific fuel consumption (BSFC), 4) brake specific energy consumption (BSEC), 5) brake thermal efficiency (BTE), and 6) exhaust gas temperature (EGT). To investigate the emissions, the authors usually examine 1) nitrogen oxides $\left(\mathrm{NO}_{\mathrm{x}}\right), 2$ ) hydrocarbon emissions (HC), 3) carbon dioxide $\left(\mathrm{CO}_{2}\right)$, 4) carbon monoxide (CO), and 5) smoke opacity (SO). In certain circumstances, blended biodiesel outperforms regular diesel fuel in terms of BP (Sahoo et al., 2009; Fattah et al., 2014). Some researches have shown that using jatropha biodiesel reduces BTE (Chauhan et al., 2010; Kathirvelu et al., 2017). BP drops as the amount of biodiesel in the fuel blend increases (Thapa et al., 2018). BTE, on the other hand, diminishes when the amount of Jatropha biodiesel in the fuel mix grows (Madiwale et al., 2018). The increasing proportion of Jatropha biodiesel in the diesel-biodiesel blend reduces HC emissions (Chauhan et al., 2012). Reksowardojo et al. (Reksowardojo et al., 2007) reported that when compared to diesel fuel, an increase in biodiesel percentage results in a reduction in $\mathrm{HC}$ emissions of 14.91-27.53 percent. Lower HC emissions are usually observed at full load conditions than other load conditions (Senthilkumar and Sankaranarayanan, 2016). In most cases, the NOx emissions from Jatropha biodiesel are greater than those from diesel fuel (Abed et al., 2019). CO emissions from Jatropha biodiesel and its blends are usually reduced by $10-40 \%$ compared to that of diesel at full load condition (Huang et al., 2010; Singh A. et al., 2021). The rise in CO emissions is noticed when the load percentage increases (Sundaresan et al., 2007). Smoke opacity falls as the biodiesel content in the blend rises, but increases when the load increases for Jatropha biodiesel and its blends (Chauhan et al., 2012; Pandhare and Padalkar, 2013). The engine performance and emissions while utilising Jatropha Curcas based biodiesel for different test conditions are summarised in Table 5.

\section{Economic Viability of Jatropha Biodiesel Production}

Francis et al. (Francis et al., 2005) reported that Jatropha Curcas thrives on underutilised locations with little water and poor soil, according to reports, and it may yield oilseed as early as the first year of growth, although on a small scale. In the tropics, the feasibility of commercialising Jatropha cultivation on fertile land to replace other food and income crops has been questioned. In the tropics, the feasibility of commercialising Jatropha Curcas cultivation on fertile land to replace other food and income crops has been questioned. Wahl et al. (Wahl et al., 2009) reported that Based on a yield of $2000 \mathrm{~kg}$ per year from mature trees, yearly operational expenditures for 1 ha of Jatropha Curcas are estimated to be about USD 200. Picking and post-harvest processing make for a large number of total expenses, they said. Thus annual expenditures are strongly reliant on production. Because Jatropha Curcas growing requires a lot of labour, it's difficult to achieve or sustain economic viability. Jatropha Curcas can be intercropped with annuals, perennials, or trees which boosts soil productivity acts as a soil cover and gives instant extra revenue to farmers (Wahl et al., 2009). When Jatropha Curcas production is low or nonexistent, yet land maintenance and opportunity expenses must be paid, this is required the most. The less space between rows for intercrops, the more soil the Jatropha Curcas plants cover. As a result, intercrop output declines with time, which does not always correspond to an increase in Jatropha Curcas yield. The use of Jatropha Curcas species local to specific countries, as well as the development of Jatropha Curcas on degraded lands that cannot now be used for agriculture, would be less problematic and more acceptable. Navarro-Pineda et al. (Navarro-Pineda et al., 2017) investigated Biodiesel production from Jatropha Curcas in Yucatán state, Mexico: economic feasibility and energy balance The nett energy ratio of biodiesel production is 2.88 when all energy outputs (glycerine, press cake, and pellets) are taken into account. The system generates more energy than it consumes if the nett energy ratio is larger than one. Biodiesel production, however, is not economically feasible based on the criteria used in this study. They estimated that achieving economic viability would need a seed yield of $3,250 \mathrm{~kg} / \mathrm{ha}$ per year. As a result, future research should concentrate on inventing, developing, and improving technology to modernise the seed gathering, seed processing, oil extraction, and biodiesel manufacturing processes. The agronomic performance, water and nutrient requirements, and pest and disease susceptibility of Jatropha should be examined in more detail for commercial and economically successful production. 
TABLE 5 | Summary of the review of engine performance and emissions by using Jatropha Curcas based biodiesel.

\begin{tabular}{|c|c|c|c|}
\hline References & Scope of the study & Performance findings & Emission findings \\
\hline Rajak et al. (2020) & $\begin{array}{l}\text { Performance and emission of JB20, JB40, JB60 } \\
\text { were evaluated in a single-cylinder diesel engine } \\
\text { operating at } 1,500 \mathrm{rpm} \text { with } \mathrm{CR}^{\mathrm{a}} 18.5 \text { and at } \\
\text { various loads }(25,50,75 \text {, and } 100 \%)\end{array}$ & $\begin{array}{l}\text { - The BTE values for JB20 are slightly lower } \\
(0.5-2.06 \%) \text { and } \\
\text { - The BSFC values for JB20 are more } \\
(3.6-2.2 \%) \text { compared to diesel fuel }\end{array}$ & $\begin{array}{l}\text { - At all engine loads, the } \mathrm{NO}_{x} \text { emission was } \\
\text { lower for Jatropha Curcas blends } \\
\text { - Jatropha Curcas blends were found to lower } \\
\text { smoke emission }\end{array}$ \\
\hline Dharma et al. (2017) & $\begin{array}{l}\text { Performance and exhaust emissions of a single- } \\
\text { cylinder DI diesel engine fuelled with biodiesel- } \\
\text { diesel mixes made from Jatropha-Curcas and } \\
\text { Ceiba Pentandra. Blending 10, 20, 30, 40, and } \\
50 \text { vol\% of J50C50 biodiesel with diesel yields } \\
\text { B10, B20, B30, B40, and B50 blends. }\end{array}$ & $\begin{array}{l}\text { When compared to other fuel mixes, the B10 } \\
\text { blend has greater engine torque, braking } \\
\text { power, and BTE, with values of } 34.07 \mathrm{Nm} \text {, } \\
3.5 \mathrm{~kW} \text {, and } 34.1 \% \text {, respectively. }\end{array}$ & $\begin{array}{l}\text { - For all of the } \mathrm{J} 50 \mathrm{C} 50 \text { biodiesel-diesel blends } \\
\text { studied in this research, the } \mathrm{B} 10 \text { blend had the } \\
\text { lowest } \mathrm{CO}, \mathrm{NO}_{\mathrm{x}} \text {, and } \mathrm{SO} \text { values at an engine } \\
\text { speed of } 1900 \mathrm{rpm} \text {. }\end{array}$ \\
\hline Kavitha et al. (2019) & $\begin{array}{l}\text { Three mixes are available: } 90 \% \text { diesel, } 7.5 \% \mathrm{JB} \text {, } \\
\text { and } 2.5 \% \text { ethanol (D 90J7.5E1.25), 95\% diesel, } \\
\text { 3.75\% JB, and } 1.25 \% \text { ethanol (D95J3.75E1.25), } \\
\text { and } 98 \% \text { diesel, } 1.5 \% \text { JB, and 0.5\% ethanol (D } \\
\text { 95J3.75E1.25) (D98J1.5E0.5). }\end{array}$ & $\begin{array}{l}\text { - When compared to diesel, the BTE of } \\
\text { D90J7.5E2.5 and D95J3.75E1.25 rose by } \\
2.13 \text { and } 3.24 \% \text {, respectively, at } 0.937 \mathrm{~kW} \text {. } \\
\text { When compared to diesel, the BSFC of the } \\
\text { blend D90J7.5E2.5 fell by } 2.68 \% \text { at } \\
0.937 \mathrm{~kW} \text {. }\end{array}$ & $\begin{array}{l}\text { - When compared to diesel, D90J7.5E2.5 } \\
\text { shows a moderate reduction in } \mathrm{NO}_{x} \\
\text { emissions, whilst D95J3.75E1.25 shows a } \\
\text { slight rise in } \mathrm{NO}_{x} \text { emissions. } \\
\text { - Increasing biodiesel mix lowered } \mathrm{HC} \text { and } \mathrm{NO}_{x} \\
\text { emissions while reducing biodiesel blend } \\
\text { reduced CO emissions. }\end{array}$ \\
\hline
\end{tabular}

Xu et al. (2017) Under light load operation of a diesel engine, the influence of fuel supply parameters on performance and emission characteristics of a $20 \%$ mix of Jatropha Curcas biodiesel (J20).

Rashed et al. (2016) In a diesel engine, the performance and emissions of moringa biodiesel (20\%) were examined and compared to palm, Jatropha Curcas, and diesel fuel.

Sahoo et al. (2009) Biodiesel (B20, B50, and B100) compares to diesel in terms of performance and emissions.

Ong et al. (2014) JB10, JB20, JB30, and JB50 engine performance and emissions were tested in a diesel engine at full load.
- The average BP for biodiesel fuel blends was somewhat lower (6.92-8.75\%) than diesel, whereas BSFC values were higher (5.42-8.39\%)
- Biodiesel blends significantly decreased CO (22.93-32.65\%) and HC (11.84-30.26\%) emissions, but somewhat increased NO (6.91-18.56\%) emissions when compared to diesel fuel.
- For a full load, the use of JB20 and JB50 showed $0.09-2.64 \%$ and $0.05-3.8 \%$ improvement in power respectively.

- Change in BSEC for JB20, JB50, JB100 were $2.86,6.0,12.37 \%$ at rated speed, respectively.

- The reduction in smoke for JB20, JB50, and JB100 at full load and rated speed was $28.57 \%, 40.9 \%$, and $64.28 \%$, respectively.

- The lowest BSFC $261 \mathrm{~g} / \mathrm{kWh}, 281 \mathrm{~g} / \mathrm{kWh}$ and $290 \mathrm{~g} / \mathrm{kWh}$ at $1900 \mathrm{rpm}$ were reported for JB10 and the highest BSFC was $401 \mathrm{~g} /$ kWh, for JB50 at 2,400 rpm.

- JCB resulted in higher BTE compared to other tested biodiesels
- JB10 had the lowest $\mathrm{NO}_{x}$ of $86.10 \mathrm{ppm}$ at $1900 \mathrm{rpm}$ and the highest $\mathrm{NO}_{x}$ of $120.36 \mathrm{ppm}$ at 2,400 rpm

- They reported a decreased $\mathrm{HC}$ emission for JB10 compared to diesel
Chauhan et al. (2010)
Preheated Jatropha Curcas oil's performance and emissions in a medium-capacity diesel engine
- Preheated Jatropha Curcas oil is indicated as a viable diesel engine fuel replacement.

- Considering the BTE (brake thermal efficiency), BSEC, and gaseous emissions, $80^{\circ} \mathrm{C}$ was determined to be the best fuel input temperature.

- The BTE of Jatropha Curcas oil that had been warmed was greater than that of unheated Jatropha Curcas oil.

- Jatropha oil (unheated or warmed) has a greater BSEC than diesel.
Elango and Senthilkumar, (2011)
Performance and emission characteristics of a diesel engine running on various Jatropha Curcas oil/diesel mixtures (10-50\%).
- The BSFC of B20 is somewhat greater than diesel, although other mixes are closer to diesel.

- For the same power output, B20 obtained a maximum brake thermal efficiency of $29.4 \%$, while diesel reached $30.9 \%$.
- Unheated Jatropha Curcas oil emits more CO than diesel fuel or warmed Jatropha Curcas oil.

- $\mathrm{HC}$ emissions are lower with warmed oil at $100{ }^{\circ} \mathrm{C}$ than with diesel.
- The exhaust gas temperatures were greater because the engine was air-cooled, which increased $\mathrm{NO}_{x}$ emissions.

- Blends of up to $20 \%$ lowered $\mathrm{CO}_{2}$ emissions significantly while just slightly lowering BTE.

(Continued on following page) 
TABLE 5 | (Continued) Summary of the review of engine performance and emissions by using Jatropha Curcas based biodiesel.

\begin{tabular}{|c|c|c|c|}
\hline References & Scope of the study & Performance findings & Emission findings \\
\hline $\begin{array}{l}\text { Agarwal and } \\
\text { Agarwal, (2007) }\end{array}$ & $\begin{array}{l}\text { The effect of raising the fuel temperature to } \\
\text { reduce the viscosity of Jatropha Curcas oil on } \\
\text { the engine's combustion and emission } \\
\text { characteristics }\end{array}$ & $\begin{array}{l}\text { - When comparing diesel with heated } \\
\text { Jatropha Curcas oil, the BSFC and EGT for } \\
\text { unheated Jatropha oil were shown to be } \\
\text { greater. } \\
\text { - Unheated Jatropha Curcas oil has a lower } \\
\text { BTE than heated Jatropha Curcas oil and } \\
\text { diesel. }\end{array}$ & $\begin{array}{l}\text { - In comparison to diesel, emission } \\
\text { characteristics rose as the quantity of } \\
\text { Jatropha Curcas oil in the blends increased. } \\
\text { - For warmed Jatropha Curcas oil, } \mathrm{CO}_{2}, \mathrm{CO} \text {, } \\
\mathrm{HC} \text {, emission, and smoke opacity were found } \\
\text { to be comparable to diesel. }\end{array}$ \\
\hline Forson et al. (2004) & $\begin{array}{l}\text { In a single-cylinder direct-injection diesel engine, } \\
\text { the performance of Jatropha Curcas oil and } \\
\text { diesel mixtures. Diesel, Jatropha Curcas oil, and } \\
\text { diesel/Jatropha Curcas oil blends of } 97.4 \% / \\
2.6 \%, 80 / 20 \% \text {, and } 50 / 50 \text { by volume were used } \\
\text { in the tests. }\end{array}$ & $\begin{array}{l}\text { - The best braking power, thermal efficiency, } \\
\text { and specific fuel consumption were attained } \\
\text { using a } 97.4 \% \text { diesel/2.6\% Jatropha blend. }\end{array}$ & $\begin{array}{l}\text { - CO readings are lower at higher loads (higher } \\
\text { than } 4 \mathrm{Nm} \text { ) for fuels with less than } 2.6 \% \text { oil by } \\
\text { volume. }\end{array}$ \\
\hline $\begin{array}{l}\text { Senthil Kumar et al. } \\
\text { (2003) }\end{array}$ & $\begin{array}{l}\text { Single fuel operation in a single-cylinder direct } \\
\text { injection diesel engine at 1,500 rpm using plain } \\
\text { Jatropha Curcas oil and its esters ( } 100 \% \text { JB) as } \\
\text { fuel. }\end{array}$ & $\begin{array}{l}\text { - When compared to diesel, Jatropha Curcas } \\
\text { oil had a somewhat lower BTE. } \\
\text { - Maximum BTEs are } 27.4,29 \text { and } 30.2 \% \text { with } \\
\text { Jatropha Curcas oil, JB and diesel. }\end{array}$ & $\begin{array}{l}\text { - Compared to diesel, both Jatropha Curcas oil } \\
\text { and JB emit more } \mathrm{HC} \text { than diesel, with } \\
\text { increases of } 10 \text { and } 30 \% \text { respectively. } \\
\text { - } \mathrm{CO}_{2} \text { emissions followed a similar pattern. } \\
\text { - Jatropha Curcas oil and JB had maximum } \\
\text { smoke levels of } 4.4 \mathrm{BSU} \text { and } 4 \mathrm{BSU} \text {, } \\
\text { respectively. It is } 3.8 \mathrm{BSU}^{\mathrm{b}} \text { in the case of } \\
\text { diesel. }\end{array}$ \\
\hline
\end{tabular}

\section{FUTURE RESEARCH DIRECTIONS}

Biodiversity is important in supporting ecosystem processes and may be thought of as a basis for ecosystem services. It may also function as an ecological service in and of itself (Mace et al., 2012). The following elements are regarded as important drivers of biodiversity loss connected with biofuels: 1 ) habitat degradation or change in land use, 2) species invasiveness, 3) pollution, and 4) climate change Among them, habitat degradation is recognised to be a significant contributor to biodiversity loss, followed by species invasiveness (Kgathi et al., 2017). It has not yet been possible to get significant and sustainable volumes of Jatropha oil for large-scale biodiesel manufacturing. As a result, the development of new Jatropha projects has been slowed, and numerous current initiative projects have been cancelled (Ewunie et al., 2021). Insufficient market opportunity, insufficient government incentives, lack of clear regulations and legislation, ownership issues, arable land scarcity, inadequate technology in seed collecting and processing, and poor agronomic performance Jatropha seed were the key obstacles to sustainable Jatropha biodiesel production.

Engine types, operating procedures, combustion processes, and diverse biodiesel fuel attributes all have a substantial impact on the performance, combustion, and emission characteristics of diesel engines running on Jatropha biodiesel. Extensive experimental effort on molecular and genetic enhancement is also required to provide enough and high-quality feedstock for long-term biodiesel production. Future research should concentrate on either increasing the fuel qualities of Jatropha biodiesel and modifying diesel engines to improve performance and emission characteristics. Finally, before developing largescale biodiesel production, the economic, social, environmental, and technological potential of Jatropha for sustainable biodiesel production should be studied.

\section{CONCLUSION}

The properties and performance of biodiesel made from Jatropha were examined and reported. In terms of raw resources, Jatrophabased biodiesel does not compete with human food because of the existence of certain harmful components, non-edible plant oils are not acceptable for human consumption, according to tests conducted around the world and findings available in the literature. Jatropha plants, unlike other food plants, do not need rich soil. These plants are widely accessible in underdeveloped nations, and they are particularly costeffective when compared to edible plant oils. When utilised in an internal combustion engine, Jatropha-based biodiesel produces less pollution. The engine performance of Jatropha biodiesel is equivalent to that of petroleum-based diesel. Good economic performance and necessary public policies are essential components in achieving commercial Jatrophabased biodiesel manufacturing success. However, Jatropha biodiesel is made through a simple triglyceride and fatty oil transesterification process that is aided by alkaline or acidic catalytic agents. The latter has a number of drawbacks; researchers have looked for enzymes that are less harmful to the environment. Furthermore, in order to maximise productivity, effective agricultural techniques that match local environmental circumstances must be used (soil, climate, etc.). Because fossil fuel (coal, oil, and gas) reserves are fast depleting, it is predicted that Jatropha-based biodiesel 
will be a viable long-term alternative. Because these fossil fuel resources are limited, if they are used over an extended period of time, global resources will ultimately run out. To summarise, the Jatropha is differentiated by the many ecological, energy, and economic advantages connected with its commercial usage, and increased use of this plant is helpful to the environment and food production.

\section{AUTHOR CONTRIBUTIONS}

TR wrote the manuscript, reviewed, improved, and compiled the whole article. AS and YP contributed to conceptualization and writing the extraction section. AS contributed to the methodology section. IF contributed to the introduction section. TM and HO oversaw the work and provided review. All authors contributed to the article and approved the submitted version.

\section{REFERENCES}

Abdelgadir, H. A., Johnson, S. D., and Van Staden, J. (2009). Pollinator Effectiveness, Breeding System, and Tests for Inbreeding Depression in the Biofuel Seed crop,Jatropha Curcas. J. Hortic. Sci. Biotechnol. 84, 319-324. doi:10.1080/14620316.2009.11512524

Abdelgadir, H. A., and Van Staden, J. (2013). Ethnobotany, Ethnopharmacology and Toxicity of Jatropha Curcas L. (Euphorbiaceae): A Review. South Afr. J. Bot. 88, 204-218. doi:10.1016/j.sajb.2013.07.021

Abdullah, M. A., Rahmah, A. U., and Man, Z. (2010). Physicochemical and Sorption Characteristics of Malaysian Ceiba Pentandra (L.) Gaertn. As a Natural Oil Sorbent. J. Hazard. Mater. 177, 683-691. doi:10.1016/ j.jhazmat.2009.12.085

Abed, K. A., Gad, M. S., El Morsi, A. K., Sayed, M. M., and Elyazeed, S. A. (2019). Effect of Biodiesel Fuels on Diesel Engine Emissions. Egypt. J. Pet. 28, 183-188. doi:10.1016/j.ejpe.2019.03.001

Achten, W. M., Nielsen, L. R., Aerts, R., Lengkeek, A. G., Kjær, E. D., Trabucco, A., et al. (2010). Towards Domestication ofJatropha Curcas. Biofuels 1, 91-107. doi:10.4155/bfs.09.4

Agarwal, A. K. (2007). Biofuels (Alcohols and Biodiesel) Applications as Fuels for Internal Combustion Engines. Prog. Energ. Combustion Sci. 33, 233-271. doi:10.1016/j.pecs.2006.08.003

Agarwal, D., and Agarwal, A. K. (2007). Performance and Emissions Characteristics of Jatropha Oil (Preheated and Blends) in a Direct Injection Compression Ignition Engine. Appl. Therm. Eng. 27, 2314-2323. doi:10.1016/ j.applthermaleng.2007.01.009

Ajila, C. M., Brar, S. K., Verma, M., Tyagi, R. D., Godbout, S., and Valéro, J. R. (2011). Extraction and Analysis of Polyphenols: Recent Trends. Crit. Rev. Biotechnol. 31, 227-249. doi:10.3109/07388551.2010.513677

Alptekin, E., and Canakci, M. (2009). Characterization of the Key Fuel Properties of Methyl Ester-Diesel Fuel Blends. Fuel 88, 75-80. doi:10.1016/j.fuel.2008.05.023

Alrashidi, M., Derawi, D., Salimon, J., and Yusoff, M. F. (2020). An Investigation of Physicochemical Properties of Nigella Sativa L. Seed Oil from Al-Qassim by Different Extraction Methods. J. King Saud University-Science 32, 3337-3342. doi:10.1016/j.jksus.2020.09.019

Ambat, I., Srivastava, V., Iftekhar, S., Haapaniemi, E., and Sillanpää, M. (2020). Effect of Different Co-solvents on Biodiesel Production from Various Low-Cost Feedstocks Using Sr-Al Double Oxides. Renew. Energ. 146, 2158-2169. doi:10.1016/j.renene.2019.08.061

Arbab, M. I., Masjuki, H. H., Varman, M., Kalam, M. A., Imtenan, S., and Sajjad, H. (2013). Fuel Properties, Engine Performance and Emission Characteristic of Common Biodiesels as a Renewable and Sustainable Source of Fuel. Renew. Sustainable Energ. Rev. 22, 133-147. doi:10.1016/j.rser.2013.01.046

\section{FUNDING}

This research was funded by ITERA, which supported this research activity and UTS. The authors wish to acknowledgement the research is supported by Institut Teknologi Sumatera under Research Grant for Hibah Publikasi GBU-45 and Pendidikan Tinggi Republik Indonesia and Politeknik Negeri Medan, Medan, Indonesia. This research is funded by the Centre for Advanced Modeling and Geospatial Information Systems (CAMGIS), UTS under Grants 321740.2232397.

\section{ACKNOWLEDGMENTS}

The authors would like to thank the Institut Teknologi Sumatera (ITERA), and Politeknik Negeri Medan, Indonesia.

Ashraful, A. M., Masjuki, H. H., Kalam, M. A., Rizwanul Fattah, I. M., Imtenan, S., Shahir, S. A., et al. (2014). Production and Comparison of Fuel Properties, Engine Performance, and Emission Characteristics of Biodiesel from Various Non-edible Vegetable Oils: A Review. Energ. Convers. Management 80, 202-228. doi:10.1016/j.enconman.2014.01.037

Atabani, A. E., Mahlia, T. M. I., Anjum Badruddin, I., Masjuki, H. H., Chong, W. T., and Lee, K. T. (2013). Investigation of Physical and Chemical Properties of Potential Edible and Non-edible Feedstocks for Biodiesel Production, a Comparative Analysis. Renew. Sustainable Energ. Rev. 21, 749-755. doi:10.1016/j.rser.2013.01.027

Ayoub, M., Yusoff, M. H. M., Nazir, M. H., Zahid, I., Ameen, M., Sher, F., et al. (2021). A Comprehensive Review on Oil Extraction and Biodiesel Production Technologies. Sustainability 13, 788. doi:10.3390/su13020788

Azad, A. K., Rasul, M. G., Khan, M. M. K., Sharma, S. C., Mofijur, M., and Bhuiya, M. M. K. (2016). Prospects, Feedstocks and Challenges of Biodiesel Production from beauty Leaf Oil and castor Oil: A Nonedible Oil Sources in Australia. Renew. Sustainable Energ. Rev. 61, 302-318. doi:10.1016/ j.rser.2016.04.013

Banerji, R., Chowdhury, A. R., Misra, G., Sudarsanan, G., Verma, S. C., and Srivastava, G. S. (1985). Jatropha Seed Oils for Energy. Biomass 8, 277-282. doi:10.1016/0144-4565(85)90060-5

Becker, K., and Makkar, H. P. (1998). Effects of Phorbol Esters in Carp (Cyprinus carpio L). Vet. Hum. Toxicol. 40, 82-86.

Bhuiya, M. M. K., Rasul, M., Khan, M., Ashwath, N., and Mofijur, M. (2020). Comparison of Oil Extraction between Screw Press and Solvent (N-hexane) Extraction Technique from beauty Leaf (Calophyllum inophyllum L.) Feedstock. Ind. Crops Prod. 144, 112024. doi:10.1016/ j.indcrop.2019.112024

Bilal, S., Mohammed-Dabo, I. A., Nuhu, M., Kasim, S. A., Almustapha, I. H., and Yamusa, Y. A. (2013). Production of Biolubricant from Jatropha Curcas Seed Oil. J. Chem. Eng. Mater. Sci. 4, 72-79. doi:10.5897/JCEMS2013.0164

Cante, R. C., Garella, I., Gallo, M., and Nigro, R. (2020). Effect of Moisture Content on the Extraction Rate of Coffee Oil from Spent Coffee Grounds Using Norflurane as Solvent. Chem. Eng. Res. Des. 165, 172-179. doi:10.1016/ j.cherd.2020.11.002

Carels, N. (2009). Chapter 2 Jatropha Curcas. Adv. Bot. Res. 50, 39-86. doi:10.1016/ s0065-2296(08)00802-1

Carreira-Casais, A., Otero, P., Garcia-Perez, P., Garcia-Oliveira, P., Pereira, A. G., Carpena, M., et al. (2021). Benefits and Drawbacks of Ultrasound-Assisted Extraction for the Recovery of Bioactive Compounds from Marine Algae. Int. J. Environ. Res. Public Health 18, 9153. doi:10.3390/ijerph18179153

Chapuis, A., Blin, J., Carré, P., and Lecomte, D. (2014). Separation Efficiency and Energy Consumption of Oil Expression Using a Screw-Press: The Case of Jatropha Curcas L. Seeds. Ind. Crops Prod. 52, 752-761. doi:10.1016/ j.indcrop.2013.11.046 
Chauhan, B. S., Kumar, N., and Cho, H. M. (2012). A Study on the Performance and Emission of a Diesel Engine Fueled with Jatropha Biodiesel Oil and its Blends. Energy 37, 616-622. doi:10.1016/j.energy.2011.10.043

Chauhan, B. S., Kumar, N., Du Jun, Y., and Lee, K. B. (2010). Performance and Emission Study of Preheated Jatropha Oil on Medium Capacity Diesel Engine. Energy 35, 2484-2492. doi:10.1016/j.energy.2010.02.043

Che Hamzah, N. H., Khairuddin, N., Siddique, B. M., and Hassan, M. A. (2020). Potential of Jatropha Curcas L. As Biodiesel Feedstock in Malaysia: A Concise Review. Processes 8, 786. doi:10.3390/pr8070786

Cunha, S. C., and Fernandes, J. O. (2018). Extraction Techniques with Deep Eutectic Solvents. Trac Trends Anal. Chem. 105, 225-239. doi:10.1016/ j.trac.2018.05.001

Danlami, J. M., Arsad, A., Zaini, M. a. A., and Sulaiman, H. (2014). A Comparative Study of Various Oil Extraction Techniques from Plants. Rev. Chem. Eng. 30, 605-626.doi:10.1515/revce-2013-0038

De Lara Lopes, N., De Almeida-Couto, J. M. F., Da Silva, C., Pereira, M. B., Pimentel, T. C., Barão, C. E., et al. (2020). Evaluation of the Effects of Pressurized Solvents and Extraction Process Parameters on Seed Oil Extraction in Pachira Aquatica. J. Supercrit. Fluids 161, 104823. doi:10.1016/ j.supflu.2020.104823

Dehgan, B. (2012). Jatropha (Euphorbiaceae), Flora Neotropical Monograph 110. New York, USA: The New York Botanical Garden Press.

Delazar, A., Nahar, L., Hamedeyazdan, S., and Sarker, S. D. (2012). Microwaveassisted Extraction in Natural Products Isolation. Methods Mol. Biol. 864, 89-115. doi:10.1007/978-1-61779-624-1_5

Demirbaş, A. (2002). Biodiesel from Vegetable Oils via Transesterification in Supercritical Methanol. Energ. Convers. Management 43, 2349-2356. doi:10.1016/S0196-8904(01)00170-4

Dharma, S., Hassan, M. H., Ong, H. C., Sebayang, A. H., Silitonga, A. S., Kusumo, F., et al. (2017). Experimental Study and Prediction of the Performance and Exhaust Emissions of Mixed Jatropha Curcas-Ceiba Pentandra Biodiesel Blends in Diesel Engine Using Artificial Neural Networks. J. Clean. Prod. 164, 618-633. doi:10.1016/j.jclepro.2017.06.065

Divakara, B. N., Upadhyaya, H. D., Wani, S. P., and Gowda, C. L. L. (2010). Biology and Genetic Improvement of Jatropha Curcas L.: A Review. Appl. Energ. 87, 732-742. doi:10.1016/j.apenergy.2009.07.013

Elango, T., and Senthilkumar, T. (2011). Performance and Emission Characteristics of CI Engine Fuelled with Non Edible Vegetable Oil and Diesel Blends. J. Eng. Sci. Technology 6, 240-250.

Elkelawy, M., Alm-Eldin Bastawissi, H., Esmaeil, K. K., Radwan, A. M., Panchal, H., Sadasivuni, K. K., et al. (2019). Experimental Studies on the Biodiesel Production Parameters Optimization of sunflower and Soybean Oil Mixture and DI Engine Combustion, Performance, and Emission Analysis Fueled with Diesel/biodiesel Blends. Fuel 255, 115791. doi:10.1016/ j.fuel.2019.115791

Emil, A., Yaakob, Z., Satheesh Kumar, M. N., Jahim, J. M., and Salimon, J. (2010). Comparative Evaluation of Physicochemical Properties of Jatropha Seed Oil from Malaysia, Indonesia and Thailand. J. Am. Oil Chem. Soc. 87, 689-695. doi:10.1007/s11746-009-1537-6

Enweremadu, C. C., and Mbarawa, M. M. (2009). Technical Aspects of Production and Analysis of Biodiesel from Used Cooking Oil-A Review. Renew. Sustainable Energ. Rev. 13, 2205-2224. doi:10.1016/j.rser.2009.06.007

Evangelista, R. L., and Cermak, S. C. (2007). Full-Press Oil Extraction of Cuphea (PSR23) Seeds. J. Am. Oil Chem. Soc. 84, 1169-1175. doi:10.1007/s11746-0071142-5

Ewunie, G. A., Morken, J., Lekang, O. I., and Yigezu, Z. D. (2021). Factors Affecting the Potential of Jatropha Curcas for Sustainable Biodiesel Production: A Critical Review. Renew. Sustainable Energ. Rev. 137, 110500. doi:10.1016/ j.rser.2020.110500

Fattah, I. M. R., Ong, H. C., Mahlia, T. M. I., Mofijur, M., Silitonga, A. S., Rahman, S. M. A., et al. (2020). State of the Art of Catalysts for Biodiesel Production. Front. Energ. Res. 8, 101. doi:10.3389/fenrg.2020.00101

Fetzer, D. L., Hamerski, F., Errico, M., and Corazza, M. L. (2020). Extraction of Cumaru Seed Oil Using Compressed Propane as Solvent. J. Supercrit. Fluids 169, 105123. doi:10.1016/j.supflu.2020.105123

Fetzer, D. L., Hamerski, F., Errico, M., and Corazza, M. L. (2021). Extraction of Cumaru Seed Oil Using Compressed Propane as Solvent. J. Supercrit. Fluids 169, 105123. doi:10.1016/j.supflu.2020.105123
Fiorini, D., Scortichini, S., Bonacucina, G., Greco, N. G., Mazzara, E., Petrelli, R., et al. (2020). Cannabidiol-enriched Hemp Essential Oil Obtained by an Optimized Microwave-Assisted Extraction Using a central Composite Design. Ind. Crops Prod. 154, 112688. doi:10.1016/ j.indcrop.2020.112688

Foidl, N., Foidl, G., Sanchez, M., Mittelbach, M., and Hackel, S. (1996). Jatropha Curcas L. As a Source for the Production of Biofuel in Nicaragua. Bioresour. Technology 58, 77-82. doi:10.1016/s0960-8524(96)00111-3

Forson, F. K., Oduro, E. K., and Hammond-Donkoh, E. (2004). Performance of Jatropha Oil Blends in a Diesel Engine. Renew. Energ. 29, 1135-1145. doi:10.1016/j.renene.2003.11.002

Francis, G., Edinger, R., and Becker, K. (2005). A Concept for Simultaneous Wasteland Reclamation, Fuel Production, and Socio-Economic Development in Degraded Areas in India: Need, Potential and Perspectives of Jatropha Plantations. Nat. Resour. Forum 29, 12-24. doi:10.1111/j.14778947.2005.00109.x

Garnayak, D. K., Pradhan, R. C., Naik, S. N., and Bhatnagar, N. (2008). Moisturedependent Physical Properties of Jatropha Seed (Jatropha Curcas L). Ind. Crops Prod. 27, 123-129. doi:10.1016/j.indcrop.2007.09.001

Gübitz, G. M., Mittelbach, M., and Trabi, M. (1999). Exploitation of the Tropical Oil Seed Plant Jatropha Curcas L. Bioresour. Technology 67, 73-82. doi:10.1016/ S0960-8524(99)00069-3

Gui, M. M., Lee, K. T., and Bhatia, S. (2008). Feasibility of Edible Oil vs. Non-edible Oil vs. Waste Edible Oil as Biodiesel Feedstock. Energy 33, 1646-1653. doi:10.1016/j.energy.2008.06.002

Guo, L., and Lee, H. K. (2011). Low-density Solvent-Based Solvent Demulsification Dispersive Liquid-Liquid Microextraction for the Fast Determination of Trace Levels of Sixteen Priority Polycyclic Aromatic Hydrocarbons in Environmental Water Samples. J. Chromatogr. A 1218, 5040-5046. doi:10.1016/ j.chroma.2011.05.069

Gutiérrez-Escobar, R., Aliaño-González, M. J., and Cantos-Villar, E. (2021). Wine Polyphenol Content and its Influence on Wine Quality and Properties: A Review. Molecules 26, 718. doi:10.3390/molecules26030718

Haile, M., Duguma, H. T., Chameno, G., and Kuyu, C. G. (2019). Effects of Location and Extraction Solvent on Physico Chemical Properties of Moringa Stenopetala Seed Oil. Heliyon 5, e02781. doi:10.1016/j.heliyon.2019.e02781

Hayyan, A., Samyudia, A. V., Hashim, M. A., Hizaddin, H. F., Ali, E., Hadj-Kali, M. K., et al. (2022). Application of Deep Eutectic Solvent as Novel Co-solvent for Oil Extraction from Flaxseed Using Sonoenergy. Ind. Crops Prod. 176, 114242. doi:10.1016/j.indcrop.2021.114242

Heller, J. (1996). "Physic Nut. Jatropha Curcas L," in Promoting the Conservation and Use of Underutilized and Neglected Crops (Roma: IBPGR), 1.

Herrera, C. M., Castellanos, M. C., Medrano, M., Harder, L., and Barrett, S. (2006). Ecology and Evolution of Flowers. Oxford: Oxford University Press.

How, H. G., Teoh, Y. H., Masjuki, H. H., and Kalam, M. A. (2012). Impact of Coconut Oil Blends on Particulate-phase PAHs and Regulated Emissions from a Light Duty Diesel Engine. Energy 48, 500-509. doi:10.1016/j.energy.2012.10.009

Huang, J., Wang, Y., Qin, J.-B., and Roskilly, A. P. (2010). Comparative Study of Performance and Emissions of a Diesel Engine Using Chinese Pistache and Jatropha Biodiesel. Fuel Process. Technology 91, 1761-1767. doi:10.1016/ j.fuproc.2010.07.017

Ibrahim, A. P., Omilakin, R. O., and Betiku, E. (2019). Optimization of MicrowaveAssisted Solvent Extraction of Non-edible Sandbox (Hura Crepitans) Seed Oil: A Potential Biodiesel Feedstock. Renew. Energ. 141, 349-358. doi:10.1016/ j.renene.2019.04.010

Ionescu, M., Voicu, G., Biriş, S.-Ş., Covaliu, C., Dincă, M., and Ungureanu, N. (2014). "Parameters Influencing the Screw Pressing Process of Oilseed Materials," in Proceeding of the 3rd International Conference on Thermal Equipment, Mamaia Resort, June 12-14 (Mamaia: Wolrdpress), 243-248.

Jain, T., Jain, V., Pandey, R., Vyas, A., and Shukla, S.(2009). Microwave Assisted Extraction for Phytoconstituents-An Overview. Asian J. Res. Chem. 2, 19-25.

Janaun, J., and Ellis, N. (2010). Perspectives on Biodiesel as a Sustainable Fuel. Renew. Sustainable Energ. Rev. 14, 1312-1320. doi:10.1016/ j.rser.2009.12.011

Janda, V., Bartle, K., and Clifford, A. A. (1993). "Supercritical Fluid Extraction in Environmental Analysis," in Applications of Supercritical Fluids in Industrial 
Analysis. Editor J. R. Dean (Dordrecht: Springer), 159-187. doi:10.1007/97894-011-2146-0_7

Kamal, S., Manmohan, S., and Birendra, S. (2011). A Review on Chemical and Medicobiological Applications of Jatropha Curcas. Int. Res. J. Pharm. 4, 61-66.

Kant Bhatia, S., Kant Bhatia, R., Jeon, J.-M., Pugazhendhi, A., Kumar Awasthi, M., Kumar, D., et al. (2021). An Overview on Advancements in Biobased Transesterification Methods for Biodiesel Production: Oil Resources, Extraction, Biocatalysts, and Process Intensification Technologies. Fuel 285, 119117. doi:10.1016/j.fuel.2020.119117

Kathirvelu, B., Subramanian, S., Govindan, N., and Santhanam, S. (2017). Emission Characteristics of Biodiesel Obtained from Jatropha Seeds and Fish Wastes in a Diesel Engine. Sustainable Environ. Res. 27, 283-290. doi:10.1016/j.serj.2017.06.004

Katwal, R., and Soni, P. (2003). Biofuels: an Opportunity for Socio-Economic Development and Cleaner Environment. Indian Forester 129, 939-949.

Kavitha, K. R., Beemkumar, N., and Rajasekar, R. (2019). Experimental Investigation of Diesel Engine Performance Fuelled with the Blends of Jatropha Curcas, Ethanol, and Diesel. Environ. Sci. Pollut. Res. 26, 8633-8639. doi:10.1007/s11356-019-04288-x

Kgathi, D. L., Mmopelwa, G., Chanda, R., Kashe, K., and Murray-Hudson, M. (2017). A Review of the Sustainability of Jatropha Cultivation Projects for Biodiesel Production in Southern Africa: Implications for Energy Policy in Botswana. Agric. Ecosyst. Environ. 246, 314-324. doi:10.1016/j.agee.2017.06.014

Khayoon, M. S., Olutoye, M. A., and Hameed, B. H. (2012). Utilization of Crude Karanj (Pongamia Pinnata) Oil as a Potential Feedstock for the Synthesis of Fatty Acid Methyl Esters. Bioresour. Technology 111, 175-179. doi:10.1016/ j.biortech.2012.01.177

Koh, M. Y., and Mohd Ghazi, T. I. (2011). A Review of Biodiesel Production from Jatropha Curcas L. Oil. Renew. Sustainable Energ. Rev. 15, 2240-2251. doi:10.1016/j.rser.2011.02.013

Kondalamahanty, A. (2021). "Indonesia’s B30 Program to Drive Global Biodiesel Production in 2021-2030: Report," in Se P Gobal.

Kumar, A., and Sharma, S. (2008). An Evaluation of Multipurpose Oil Seed Crop for Industrial Uses (Jatropha Curcas L.): A Review. Ind. Crops Prod. 28, 1-10. doi:10.1016/j.indcrop.2008.01.001

Kumar, A., and Sharma, S. (2011). Potential Non-edible Oil Resources as Biodiesel Feedstock: An Indian Perspective. Renew. Sustainable Energ. Rev. 15, 1791-1800. doi:10.1016/j.rser.2010.11.020

Kumar, R. C., Benal, M. M., Prasad, B. D., Krupashankara, M. S., Kulkarni, R. S., and Siddaligaswamy, N. H. (2018). Microwave Assisted Extraction of Oil from Pongamia Pinnata Seeds. Mater. Today Proc. 5, 2960-2964. doi:10.1016/ j.matpr.2018.01.094

Kusmiyati, K., Prasetyoko, D., Murwani, S., Fadhilah, M. N., Oetami, T. P., Hadiyanto, H., et al. (2019). Biodiesel Production from Reutealis Trisperma Oil Using KOH Impregnated Eggshell as a Heterogeneous Catalyst. Energies 12 , 1-11. doi:10.3390/en12193714

Kuti, O. A., Zhu, J., Nishida, K., Wang, X., and Huang, Z. (2013). Characterization of spray and Combustion Processes of Biodiesel Fuel Injected by Diesel Engine Common Rail System. Fuel 104, 838-846. doi:10.1016/j.fuel.2012.05.014

Lieberz, S. (2021). Biofuel Mandates in the EU by Member State and United Kingdom - 2021. Global Agricultural Information Network. (GAIN).

Mace, G. M., Norris, K., and Fitter, A. H. (2012). Biodiversity and Ecosystem Services: a Multilayered Relationship. Trends Ecol. Evol. 27, 19-26. doi:10.1016/ j.tree.2011.08.006

Madiwale, S., Karthikeyan, A., and Bhojwani, V. (2018). Properties Investigation and Performance Analysis of a Diesel Engine Fuelled with Jatropha, Soybean, Palm and Cottonseed Biodiesel Using Ethanol as an Additive. Mater. Today Proc. 5, 657-664. doi:10.1016/j.matpr.2017.11.130

Mahapatra, A. K., and Mitchell, C. P. (1999). Biofuel Consumption, Deforestation, and Farm Level Tree Growing in Rural India. Biomass and Bioenergy 17, 291-303. doi:10.1016/s0961-9534(99)00056-2

Manik, N., and Prabu, D. S. N. (2013). Experimental Analysis of Jatropha Curcas Bio-Diesel for Optimum Blend Characteristics. Bijiems 3, 63-69. doi:10.9756/ bijiems. 4667

Mariana, I., Nicoleta, U., Sorin-Ştefan, B., Gheorghe, V., and Mirela, D. (2013). ACTUAL METHODS FOR OBTAINING VEGETABLE OIL FROM OILSEEDS.
Meher, L. C., Churamani, C. P., Arif, M., Ahmed, Z., and Naik, S. N. (2013). Jatropha Curcas as a Renewable Source for Bio-Fuels-A Review. Renew. Sustainable Energ. Rev. 26, 397-407. doi:10.1016/j.rser.2013.05.065

Melvin Jose, D. F., Edwin Raj, R., Durga Prasad, B., Robert Kennedy, Z., and Mohammed Ibrahim, A. (2011). A Multi-Variant Approach to Optimize Process Parameters for Biodiesel Extraction from Rubber Seed Oil. Appl. Energ. 88, 2056-2063. doi:10.1016/j.apenergy.2010.12.024

Milano, J., Ong, H. C., Masjuki, H. H., Silitonga, A. S., Chen, W.-H., Kusumo, F. et al. (2018). Optimization of Biodiesel Production by Microwave IrradiationAssisted Transesterification for Waste Cooking Oil-Calophyllum Inophyllum Oil via Response Surface Methodology. Energ. Convers. Manag. 158, 400-415. doi:10.1016/j.enconman.2017.12.027

Mizik, T., and Gyarmati, G. (2021). Economic and Sustainability of Biodiesel Production-A Systematic Literature Review. Clean. Technol. 3, 19-36. doi:10.3390/cleantechnol3010002

Mohammed-Dabo, I., Ahmad, M., Hamza, A., Muazu, K., and Aliyu, A. (2012). Cosolvent Transesterification of Jatropha Curcas Seed Oil. J. Pet. Technol. Altern. Fuels 3, 42-51. doi:10.5897/JPTAF11.038

Moser, B. R. (2011). "Biodiesel Production, Properties, and Feedstocks," in Biofuels. Editors D. Tomes, P. Lakshmanan, and D. Songstad (New York: Springer), 285-347. doi:10.1007/978-1-4419-7145-6_15

Nasir, M., Memon, G., Valhari, M., and Khatri, L. (1988). Studies on Fixed Oil of Jatropha Curcas Seeds. Pakistan J. Scientific Ind. Res. 31, 566-568.

Navarro-Pineda, F. S., Ponce-Marbán, D. V., Sacramento-Rivero, J. C., and Barahona-Pérez, L. F. (2017). An Economic Model for Estimating the Viability of Biodiesel Production fromJatropha curcasL. J. Chem. Technol. Biotechnol. 92, 971-980. doi:10.1002/jctb.5058

Nayak, B., and Patel, K. (2010). Pharmacognostic Studies of the Jatropha Curcas Leaves. methodology 1, 6-18.

Naziri, E., Glisic, S. B., Mantzouridou, F. T., Tsimidou, M. Z., Nedovic, V., and Bugarski, B. (2016). Advantages of Supercritical Fluid Extraction for Recovery of Squalene from Wine Lees. J. Supercrit. Fluids 107, 560-565. doi:10.1016/ j.supflu.2015.07.014

Ng, J.-H., Ng, H. K., and Gan, S. (2012). Characterisation of Engine-Out Responses from a Light-Duty Diesel Engine Fuelled with palm Methyl Ester (PME). Appl. Energ. 90, 58-67. doi:10.1016/j.apenergy.2011.01.028

Nurfatriani, F., RamawatiSari, G. K., and Komarudin, H. (2019). Optimization of Crude palm Oil Fund to Support Smallholder Oil palm Replanting in Reducing Deforestation in Indonesia. Sustainability (Switzerland) 11, 1-16. doi:10.3390/ su11184914

Ofori-Boateng, C., Keat Teong, L., and Jitkang, L. (2012). Comparative Exergy Analyses of Jatropha Curcas Oil Extraction Methods: Solvent and Mechanical Extraction Processes. Energ. Convers. Management 55, 164-171. doi:10.1016/ j.enconman.2011.11.005

Ong, H. C., Masjuki, H. H., Mahlia, T. M. I., Silitonga, A. S., Chong, W. T., and Yusaf, T. (2014). Engine Performance and Emissions Using Jatropha Curcas, Ceiba Pentandra and Calophyllum inophyllum Biodiesel in a CI Diesel Engine. Energy 69, 427-445. doi:10.1016/j.energy.2014.03.035

Ong, H. C., Tiong, Y. W., Goh, B. H. H., Gan, Y. Y., Mofijur, M., Fattah, I. M. R., et al. (2021). Recent Advances in Biodiesel Production from Agricultural Products and Microalgae Using Ionic Liquids: Opportunities and Challenges. Energ. Convers. Management 228, 113647. doi:10.1016/ j.enconman.2020.113647

Openshaw, K. (2000). A Review of Jatropha Curcas: an Oil Plant of Unfulfilled Promise. Biomass and Bioenergy 19, 1-15. doi:10.1016/s0961-9534(00) 00019-2

Pandhare, A., and Padalkar, A. (2013). Investigations on Performance and Emission Characteristics of Diesel Engine with Biodiesel (Jatropha Oil) and its Blends. J. Renew. Energ. 2013, 163829. doi:10.1155/2013/163829

Perumal, S., and Sanmugam, V. (2015). Fabrication and Categorization of Bioplant Methyl Ester. SSRG Int. J. Mater. Sci. Eng. (Ssrg-ijmse) 1, 5-8. doi:10.14445/ 23948884/IJMSE-V1I1P102

Pinzi, S., Garcia, I. L., Lopez-Gimenez, F. J., Luque De Castro, M. D., Dorado, G., and Dorado, M. P. (2009). The Ideal Vegetable Oil-Based Biodiesel Composition: A Review of Social, Economical and Technical Implications. Energy Fuels 23, 2325-2341. doi:10.1021/ef801098a 
Primandari, S. R. P., Islam, A. A., Yaakob, Z., and Chakrabarty, S. (2018). Jatropha Curcas L. Biomass Waste and its Utilization. Oxford: Oxford University Press. doi:10.5772/intechopen.72803

Putri, E. M. M., Rachimoellah, M., Santoso, N., and Pradana, F. (2012). Biodiesel Production from Kapok Seed Oil (Ceiba Pentandra) through the Transesterification Process by Using Cao as Catalyst. Glob. J. Res. Eng. 12.

Rajak, U., Chaurasiya, P. K., Nashine, P., Verma, M., Reddy Kota, T., and Verma, T. N. (2020). Financial Assessment, Performance and Emission Analysis of Moringa Oleifera and Jatropha Curcas Methyl Ester Fuel Blends in a Singlecylinder Diesel Engine. Energ. Convers. Management 224, 113362. doi:10.1016/ j.enconman.2020.113362

Rajeshwaran, M., Ramasamy, S., Parthasarathi, R., and Ponshanmugakumar, A. (2020). A Critical Evaluation of Oil Extraction and Fatty Acid Composition of Prosopis Julifera. Mater. Today Proc. 33 , 4630-4634. doi:10.1016/ j.matpr.2020.08.291

Raju, A. S., and Ezradanam, V. (2002). Pollination Ecology and Fruiting Behaviour in a Monoecious Species Jatropha Curcas L.(Euphorbiaceae). CURRENT SCIENCE-BANGALORE- 83, 1395-1397.

Ramesh, D., Samapathrajan, A., and Venkatachalam, P. (2006). Production of Biodiesel from Jatropha Curcas Oil by Using Pilot Biodiesel Plant. India: Agrl. Engg. College \& Research Institute, Tamil Nadu Agricultural University-India.

Rao, P. V., and Rao, G. S. (2013). Production and Characterization of Jatropha Oil Methyl Ester. Int. J. Eng. Res. 2, 141-145.

Rashed, M. M., Kalam, M. A., Masjuki, H. H., Mofijur, M., Rasul, M. G., and Zulkifli, N. W. M. (2016). Performance and Emission Characteristics of a Diesel Engine Fueled with palm, Jatropha, and Moringa Oil Methyl Ester. Ind. Crops Prod. 79, 70-76. doi:10.1016/j.indcrop.2015.10.046

Rasul, M. G. (2018). Conventional Extraction Methods Use in Medicinal Plants, Their Advantages and Disadvantages. Int. J. Basic Sci. Appl. Comput. 2, 10-14.

Razak, N. H., Hashim, H., Yunus, N. A., and Klemeš, J. J. (2021). Reducing Diesel Exhaust Emissions by Optimisation of Alcohol Oxygenates Blend with Diesel/biodiesel. J. Clean. Prod. 316, 128090. doi:10.1016/ j.jclepro.2021.128090

Reksowardojo, I. K., Lubis, I. H., Manggala, W., Brodjonegoro, T. P., Soerawidjaja, T. H., Arismunandar, W., et al. (2007). Performance and Exhaust Gas Emissions of Using Biodiesel Fuel from Physic Nut (Jatropha Curcas L.) Oil on a Direct Injection Diesel Engine (DI). SAE Int. 2007, 11-19. doi:10.4271/ 2007-01-2025

Rizwanul Fattah, I. M., Masjuki, H. H., Kalam, M. A., Wakil, M. A., Rashedul, H. K., and Abedin, M. J. (2014). Performance and Emission Characteristics of a CI Engine Fueled with Cocos Nucifera and Jatropha Curcas B20 Blends Accompanying Antioxidants. Ind. Crops Prod. 57, 132-140. doi:10.1016/ j.indcrop.2014.03.022

Romanić, R. (2020). “Chapter 17 - Cold Pressed sunflower (Helianthus Annuus L) Oil," in Cold Pressed Oils: Green Technology, Bioactive Compounds, Functionality, and Applications. Editor M. F. Ramadan (Academic Press), $197-218$.

Sahoo, P. K., Das, L. M., Babu, M. K. G., Arora, P., Singh, V. P., Kumar, N. R., et al. (2009). Comparative Evaluation of Performance and Emission Characteristics of Jatropha, Karanja and Polanga Based Biodiesel as Fuel in a Tractor Engine. Fuel 88, 1698-1707. doi:10.1016/j.fuel.2009.02.015

Sairam, P., Ghosh, S., Jena, S., Rao, K., and Banji, D. (2012). Supercritical Fluid Extraction (SFE)-an Overview. Asian J. Res. Pharm. Sci. 2, 112-120.

Salaheldeen, M., Mariod, A. A., Aroua, M. K., Rahman, S. M. A., Soudagar, M. E. M., and Fattah, I. M. R. (2021). Current State and Perspectives on Transesterification of Triglycerides for Biodiesel Production. Catalysts 11, 1121. doi:10.3390/catal11091121

Saleem, M., and Ahmad, N. (2018). Characterization of Canola Oil Extracted by Different Methods Using Fluorescence Spectroscopy. PloS One 13, e0208640. doi:10.1371/journal.pone.0208640

Samniang, A., Tipachan, C., and Kajorncheappun-Ngam, S. (2014). Comparison of Biodiesel Production from Crude Jatropha Oil and Krating Oil by Supercritical Methanol Transesterification. Renew. Energ. 68, 351-355. doi:10.1016/ j.renene.2014.01.039

Saravanan, N., Nagarajan, G., and Puhan, S. (2010). Experimental Investigation on a DI Diesel Engine Fuelled with Madhuca Indica Ester and Diesel Blend. Biomass and Bioenergy 34, 838-843. doi:10.1016/j.biombioe.2010.01.028
Sarin, A., Arora, R., Singh, N. P., Sarin, R., and Malhotra, R. K. (2010). Blends of Biodiesels Synthesized from Non-edible and Edible Oils: Influence on the OS (Oxidation Stability). Energy 35, 3449-3453. doi:10.1016/j.energy.2010.04.039

Sarin, R., Sharma, M., Sinharay, S., and Malhotra, R. K. (2007). Jatropha-Palm Biodiesel Blends: An Optimum Mix for Asia. Fuel 86, 1365-1371. doi:10.1016/ j.fuel.2006.11.040

Senthil Kumar, M., Ramesh, A., and Nagalingam, B. (2003). An Experimental Comparison of Methods to Use Methanol and Jatropha Oil in a Compression Ignition Engine. Biomass and Bioenergy 25, 309-318. doi:10.1016/s09619534(03)00018-7

Senthilkumar, P., and Sankaranarayanan, G. (2016). Effect of Jatropha Methyl Ester on Waste Plastic Oil Fueled DI Diesel Engine. J. Energ. Inst. 89, 504-512. doi:10.1016/j.joei.2015.07.006

Sharma, A. K., Gangwar, M., Kumar, D., Nath, G., Kumar Sinha, A. S., and Tripathi, Y. B. (2016). Phytochemical Characterization, Antimicrobial Activity and Reducing Potential of Seed Oil, Latex, Machine Oil and Presscake of Jatropha Curcas. Avicenna J. Phytomed. 6, 366-375.

Sharma, Y. C., Singh, B., and Korstad, J. (2009). High Yield and Conversion of Biodiesel from a Nonedible Feedstock (Pongamia Pinnata). J. Agric. Food Chem. 58, 242-247. doi:10.1021/jf903227e

Sharudina, H., Abdullahb, N. R., Mamatb, A., Badrulhisamb, N., and Mamatc, R. (2018). Application of Alcohol Fuel Properties in Spark Ignition Engine: A Review. Jurnal Kejuruteraan SI 1, 37-47. doi:10.17576/jkukm-2018-si1(7)-05

Siddiki, S. Y. A., Uddin, M. N., Mofijur, M., Fattah, I. M. R., Ong, H. C., Lam, S. S., et al. (2021). Theoretical Calculation of Biogas Production and Greenhouse Gas Emission Reduction Potential of Livestock, Poultry and Slaughterhouse Waste in Bangladesh. J. Environ. Chem. Eng. 9, 105204. doi:10.1016/j.jece.2021.105204

Silitonga, A. S., Mahlia, T. M. I., Kusumo, F., Dharma, S., Sebayang, A. H., Sembiring, R. W., et al. (2019). Intensification of Reutealis Trisperma Biodiesel Production Using Infrared Radiation: Simulation, Optimisation and Validationfication of Reutealis Trisperma Biodiesel Production Using Infrared Radiation: Simulation, Optimisation and Validation. Renew. Energ. 133, 520-527. doi:10.1016/j.renene.2018.10.023

Singh, A., Sinha, S., Choudhary, A. K., Sharma, D., Panchal, H., and Sadasivuni, K. K. (2021a). An Experimental Investigation of Emission Performance of Heterogenous Catalyst Jatropha Biodiesel Using RSM. Case Stud. Therm. Eng. 25, 100876. doi:10.1016/j.csite.2021.100876

Singh, D., Sharma, D., Soni, S. L., Inda, C. S., Sharma, S., Sharma, P. K., et al. (2021b). A Comprehensive Review of Physicochemical Properties, Production Process, Performance and Emissions Characteristics of 2nd Generation Biodiesel Feedstock: Jatropha Curcas. Fuel 285, 119110. doi:10.1016/ j.fuel.2020.119110

Singh, R., and Padhi, S. K. (2009). Characterization of Jatropha Oil for the Preparation of Biodiesel. Nat. Prod. radiance 8, 127-132.

Staubmann, R., Foidl, G., Foidl, N., Gübitz, G. M., Lafferty, R. M., Valencia Arbizu, V. M., et al. (1997). Biogas Production fromJatropha Curcas Press-Cake. Appl. Biochem. Biotechnol. 63-65, 457-467. doi:10.1007/bf02920446

Stevanato, N., and Da Silva, C. (2019). Radish Seed Oil: Ultrasound-Assisted Extraction Using Ethanol as Solvent and Assessment of its Potential for Ester Production. Ind. Crops Prod. 132, 283-291. doi:10.1016/j.indcrop.2019.02.032

Subroto, E., Manurung, R., Heeres, H. J., and Broekhuis, A. A. (2015). Optimization of Mechanical Oil Extraction from Jatropha Curcas L. Kernel Using Response Surface Method. Ind. Crops Prod. 63, 294-302. doi:10.1016/ j.indcrop.2014.08.050

Suganya, T., Kasirajan, R., and Renganathan, S. (2014). Ultrasound-enhanced Rapid In Situ Transesterification of marine Macroalgae Enteromorpha Compressa for Biodiesel Production. Bioresour. Technol. 156, 283-290. doi:10.1016/j.biortech.2014.01.050

Sundaresan, M., Chandrasekaran, S., and Porai, P. T. (2007). Analysis of Combustion, Performance and Emission Characteristics of Blends of Methyl Esters of Jatropha Oil (MEJ) in DI Diesel Engine. Society of Automotive Engineers of Japan.

Taheripour, F., Hertel, T. W., and Ramankutty, N. (2019). Market-mediated Responses Confound Policies to Limit Deforestation from Oil palm Expansion in Malaysia and Indonesia. Proc. Natl. Acad. Sci. USA 116, 19193-19199. doi:10.1073/pnas.1903476116

Takase, M., Zhao, T., Zhang, M., Chen, Y., Liu, H., Yang, L., et al. (2015). An Expatiate Review of Neem, Jatropha, Rubber and Karanja as Multipurpose Non-edible Biodiesel 
Resources and Comparison of Their Fuel, Engine and Emission Properties. Renew. Sustainable Energ. Rev. 43, 495-520. doi:10.1016/j.rser.2014.11.049

Tan, S. X., Ong, H. C., Lim, S., Pang, Y. L., and Milano, J. (2019). Process Intensification of Biodiesel Synthesis via Ultrasound-assistedin Situesterification ofJatrophaoil Seeds. J. Chem. Technol. Biotechnol. 94, 1362-1373. doi:10.1002/jctb.5869

Tat, M. E., and Van Gerpen, J. H. (1999). The Kinematic Viscosity of Biodiesel and its Blends with Diesel Fuel. J. Amer Oil Chem. Soc. 76, 1511-1513. doi:10.1007/s11746999-0194-0

Teo, S. H., Islam, A., Chan, E. S., Thomas Choong, S. Y., Alharthi, N. H., TaufiqYap, Y. H., et al. (2019). Efficient Biodiesel Production from Jatropha Curcus Using CaSO4/Fe2O3-SiO2 Core-Shell Magnetic Nanoparticles. J. Clean. Prod. 208, 816-826. doi:10.1016/j.jclepro.2018.10.107

Thapa, S., Indrawan, N., and Bhoi, P. R. (2018). An Overview on Fuel Properties and Prospects of Jatropha Biodiesel as Fuel for Engines. Environ. Technology Innovation 9, 210-219. doi:10.1016/j.eti.2017.12.003

Tsoutsos, T., Tournaki, S., Gkouskos, Z., Paraíba, O., Giglio, F., García, P. Q., et al. (2019). Quality Characteristics of Biodiesel Produced from Used Cooking Oil in Southern Europe. ChemEngineering 3, 19. doi:10.3390/chemengineering3010019

Tsubaki, S., Oono, K., Onda, A., Kadono, T., Adachi, M., and Mitani, T. (2019). Microwave-assisted Solubilization of Microalgae in High-Temperature Ethylene Glycol. Biomass and Bioenergy 130, 105360. doi:10.1016/j.biombioe.2019.105360

Valipour, A. (2014). A Review on Combustion, Performance and Emission Characteristics of Liquid Alternative Fuels for Diesel Engine. Oxford: Oxford University Press.

Vyas, D. K., and Singh, R. N. (2007). Feasibility Study of Jatropha Seed Husk as an Open Core Gasifier Feedstock. Renew. Energ. 32, 512-517. doi:10.1016/j.renene.2006.06.006

Wahl, N., Jamnadass, R., Baur, H., Munster, C., and Iiyama, M. (2009). "Economic Viability of Jatropha Curcas L. Plantations in Northern Tanzania," in Assessing Farmers' Prospects via Cost-Benefit Analysis (Nairobi: World Agroforestry Centre). Available at: http://citeseerx.ist.psu.edu/viewdoc/download?doi=10. 1.1.608.

Wang, R., Hanna, M. A., Zhou, W.-W., Bhadury, P. S., Chen, Q., Song, B.-A., et al. (2011). Production and Selected Fuel Properties of Biodiesel from Promising Nonedible Oils: Euphorbia Lathyris L., Sapium Sebiferum L. And Jatropha Curcas L. Bioresour. Technol. 102, 1194-1199. doi:10.1016/j.biortech.2010.09.066

Wang, X.-R., and Ding, G.-J. (20122012). Reproductive Biology Characteristic of Jatropha Curcas (Euphorbiaceae). Rev. Biol. Trop. 60 (4), 1525-1533. doi:10.15517/rbt.v60i4.2070

Xiong, K., and Chen, Y. (2020). Supercritical Carbon Dioxide Extraction of Essential Oil from Tangerine Peel: Experimental Optimization and Kinetics Modelling. Chem. Eng. Res. Des. 164, 412-423. doi:10.1016/ j.cherd.2020.09.032
Xu, H., Yin, B., Liu, S., and Jia, H. (2017). Performance Optimization of Diesel Engine Fueled with Diesel-Jatropha Curcas Biodiesel Blend Using Response Surface Methodology. J. Mech. Sci. Technol. 31, 4051-4059. doi:10.1007/ s12206-017-0753-5

Yate, A. V., Narváez, P. C., Orjuela, A., Hernández, A., and Acevedo, H. (2020). A Systematic Evaluation of the Mechanical Extraction of Jatropha Curcas L. Oil for Biofuels Production. Food Bioproducts Process. 122, 72-81. doi:10.1016/ j.fbp.2020.04.001

Yunus Khan, T. M., Atabani, A. E., Badruddin, I. A., Ankalgi, R. F., Mainuddin Khan, T. K., and Badarudin, A. (2015). Ceiba Pentandra , Nigella Sativa and Their Blend as Prospective Feedstocks for Biodiesel. Ind. Crops Prod. 65, 367-373. doi:10.1016/j.indcrop.2014.11.013

Zapata, N., Vargas, M., Reyes, J. F., and Belmar, G. (2012). Quality of Biodiesel and Press Cake Obtained from Euphorbia Lathyris, Brassica Napus and Ricinus communis. Ind. Crops Prod. 38, 1-5. doi:10.1016/ j.indcrop.2012.01.004

Zhang, Q.-W., Lin, L.-G., and Ye, W.-C. (2018). Techniques for Extraction and Isolation of Natural Products: a Comprehensive Review. Chin. Med. 13, 20. doi:10.1186/s13020-018-0177-x

Zhang, Y., Chang, C., Tan, B., Xu, D., Wang, Y., and Qi, T. (2019). Application of a Sustainable Bioderived Solvent (Biodiesel) for Phenol Extraction. Acs Omega 4, 10431-10437. doi:10.1021/acsomega.9b00977

Zougagh, M., Valcárcel, M., and Ri'os, A. (2004). Supercritical Fluid Extraction: a Critical Review of its Analytical Usefulness. Trac Trends Anal. Chem. 23, 399-405. doi:10.1016/s0165-9936(04)00524-2

Conflict of Interest: The authors declare that the research was conducted in the absence of any commercial or financial relationships that could be construed as a potential conflict of interest.

Publisher's Note: All claims expressed in this article are solely those of the authors and do not necessarily represent those of their affiliated organizations, or those of the publisher, the editors, and the reviewers. Any product that may be evaluated in this article, or claim that may be made by its manufacturer, is not guaranteed or endorsed by the publisher.

Copyright (c) 2022 Riayatsyah, Sebayang, Silitonga, Padli, Fattah, Kusumo, Ong and Mahlia. This is an open-access article distributed under the terms of the Creative Commons Attribution License (CC BY). The use, distribution or reproduction in other forums is permitted, provided the original author(s) and the copyright owner(s) are credited and that the original publication in this journal is cited, in accordance with accepted academic practice. No use, distribution or reproduction is permitted which does not comply with these terms. 